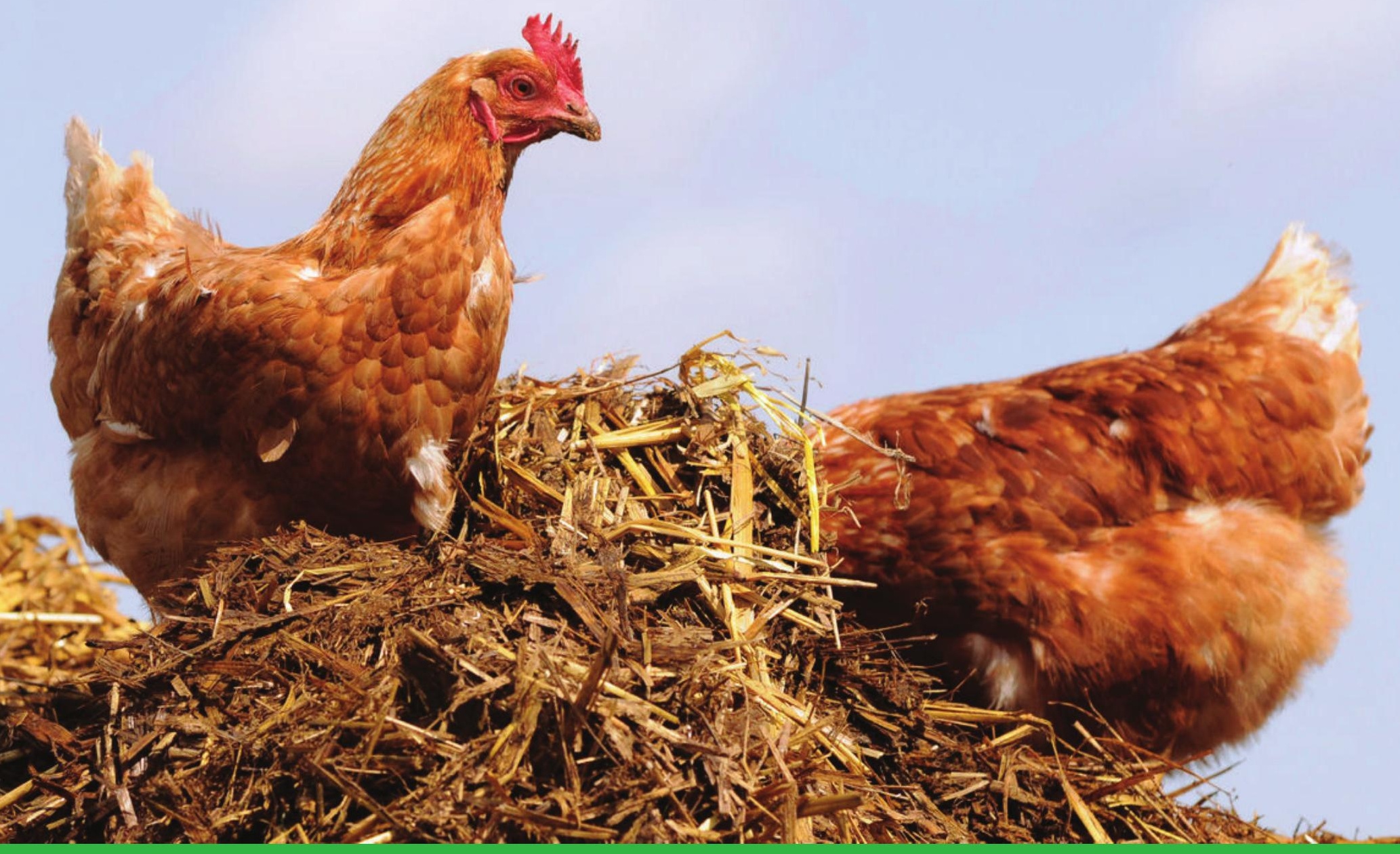

\title{
Inventarisatie mestverwerkingsopgave in gemeente Ede en omstreken
}





\section{Inventarisatie mestverwerkingsopgave in gemeente Ede en omstreken}

T.J.A. Gies, J. Kros en J.C. Voogd

Dit onderzoek is uitgevoerd door Wageningen Environmental Research (Alterra) in opdracht van en gefinancierd door de gemeente Ede.

Wageningen Environmental Research

Wageningen, maart 2017

Rapport 2801

ISSN 1566-7197 
Gies, T.J.A., J. Kros en J.C. Voogd, 2017. Inventarisatie mestverwerkingsopgave in gemeente Ede en omstreken. Wageningen, Wageningen Environmental Research, Rapport 2801. 40 blz.; 16 fig.; 7 tab.; 15 ref.

Het gebruik van dierlijke mest is wettelijk beperkt, omdat te veel meststoffen uit dierlijke mest in grond- en oppervlaktewater terechtkomen. Het overschot aan dierlijke mest moet gedeeltelijk worden verwerkt en buiten de Nederlandse landbouwsector worden afgezet. Om aan de mestverwerkingsplicht te voldoen, is mestverwerkingscapaciteit nodig.

In de gemeente Ede kan 95\% van de geproduceerde mest (uitgedrukt in kg fosfaat) niet op eigen grond worden toegediend. Het gaat met name om pluimvee-, varkens- en kalvermest. De overtollige mest wordt naar verschillende gebieden in Nederland en het buitenland getransporteerd. Een deel van deze mest wordt weer in de landbouw toegediend op de landbouwgronden, een deel wordt verwerkt tot producten die buiten de landbouw afgezet worden.

De verwachting is dat op landelijk niveau de mestverwerkingscapaciteit binnen afzienbare tijd in evenwicht is met de te verwerken mestoverschotten. De mestverwerkingscapaciteit in de regio Oost is laag in verhouding tot de mest die verwerkt moeten worden. De gemeente Ede neemt een positieve grondhouding aan ten opzichte van initiatieven die bijdragen aan (een deel van) de oplossing van de mestproblematiek in de gemeente en de regio, omdat ze belang hechten aan een vitale agrarische sector in de gemeente.

Trefwoorden: mestverwerking, gemeente Ede, Food Valley, mestverwerkingscapaciteit, mesttransport, mestoverschot, mestverwerkingsplicht

Dit rapport is gratis te downloaden van http://dx.doi.org/10.18174/411801 of op www.wur.nl/environmental-research (ga naar 'Wageningen Environmental Research' in de grijze balk onderaan). Wageningen Environmental Research verstrekt geen gedrukte exemplaren van rapporten.

(C) 2017 Wageningen Environmental Research (instituut binnen de rechtspersoon Stichting Wageningen Research), Postbus 47, 6700 AA Wageningen, T 03174807 00, E info.alterra@wur.nl, www.wur.nl/environmental-research. Wageningen Environmental Research is onderdeel van Wageningen University \& Research.

- Overname, verveelvoudiging of openbaarmaking van deze uitgave is toegestaan mits met duidelijke bronvermelding.

- Overname, verveelvoudiging of openbaarmaking is niet toegestaan voor commerciële doeleinden en/of geldelijk gewin.

- Overname, verveelvoudiging of openbaarmaking is niet toegestaan voor die gedeelten van deze uitgave waarvan duidelijk is dat de auteursrechten liggen bij derden en/of zijn voorbehouden.

Wageningen Environmental Research aanvaardt geen aansprakelijkheid voor eventuele schade voortvloeiend uit het gebruik van de resultaten van dit onderzoek of de toepassing van de adviezen.

Wageningen Environmental Research Rapport 2801 | ISSN 1566-7197

Foto omslag: Shutterstock 


\section{Inhoud}

$\begin{array}{ll}\text { Samenvatting } & 5\end{array}$

1

Inleiding 9

1.1 Probleemstelling $\quad 9$

1.2 Projectdoelstelling 9

$\begin{array}{lll}1.3 & \text { Onderzoeksaanpak } & 10\end{array}$

$2 \quad$ Mestbeleid $r 1$

2.1 Meststoffenwet $\quad 11$

2.2 Mest verwerken en mestverwerkingsplicht $\quad 12$

$3 \quad$ Aard en omvang mestproblematiek in gemeente Ede en omgeving 15

3.1 Veehouderij in gemeente Ede en omringende gemeenten $\quad 15$

$\begin{array}{lll}3.2 & \text { Mestproductie } & 16\end{array}$

$\begin{array}{lll}3.3 & \text { Mesttransport } & 18\end{array}$

$\begin{array}{lll}3.4 & \text { Mestverwerking } & 20\end{array}$

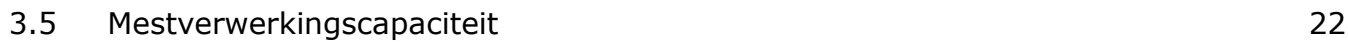

4 Ruimtelijke ordening en mestbewerking en -verwerking 25

$\begin{array}{lll}4.1 & \text { Landelijk beleid } & 25\end{array}$

$\begin{array}{lll}4.2 & \text { Provinciaal beleid } & 25\end{array}$

$\begin{array}{lll}4.3 & \text { Gemeentelijk beleid Ede } & 26\end{array}$

$5 \quad$ Ontwikkelingen mestverwerking $\quad 27$

$\begin{array}{lll}5.1 & \text { Kansen en bedreigingen } & 27\end{array}$

5.1.1 Ontwikkelingen mestbewerking en -verwerking 27

$\begin{array}{ll}5.1 .2 \text { Bedreigingen } & 29\end{array}$

$\begin{array}{lll}5.2 & \text { Resultaten expertmeeting } & 30\end{array}$

$6 \quad$ Conclusies en aanbevelingen $\quad 32$

6.1 Conclusies $\quad 32$

6.2 Aanbevelingen 33

$\begin{array}{ll}\text { Literatuur } & 34\end{array}$

Bijlage 1 Berekeningsprocedure mestoverschot 35

Bijlage 2 Lijst met deelnemers expertmeeting 36

$\begin{array}{lll}\text { Bijlage } 3 & \text { Mestproductie, -transport en verwerking } & 37\end{array}$ 



\section{Samenvatting}

\section{Achtergrond en doelstelling inventarisatie mestverwerkingsopgave Ede en omstreken}

Het gebruik van dierlijke mest is wettelijk beperkt, omdat te veel dierlijke meststoffen in grond- en oppervlaktewater terechtkomen en dit verontreinigen. In de praktijk betekent dit dat een deel van de geproduceerde dierlijke mest in Nederland overblijft (mestoverschot). Deze mest moet worden verwerkt en buiten de Nederlandse landbouwsector worden afgezet. Sinds 2014 is in de Meststoffenwet daarvoor een mestverwerkingsplicht voor bedrijven met een mestoverschot opgenomen.

Voor de mestverwerkingsplicht is mestverwerkingscapaciteit nodig. De gemeente Ede neemt een positieve grondhouding aan ten opzichte van initiatieven die bijdragen aan (een deel van) de oplossing van de mestproblematiek in de gemeente en de regio, temeer omdat ze belang hecht aan een vitale agrarische sector in de gemeente. Wel is er behoefte aan inzicht in welke opgaven er liggen op gemeentelijk en regionaal niveau en wat daarvoor de beste oplossingen zijn.

In deze studie is een kwantitatieve data-analyse uitgevoerd waarin modelberekeningen gecombineerd zijn met data over mesttransporten. Deze analyse is aangevuld met een documentenanalyse en de resultaten van een expertmeeting met regionale experts met kennis van de agrarische sector en mestverwerking.

\section{Mestverwerkingsplicht}

De verplichting om mest te laten verwerken, geldt alleen als er op het agrarische bedrijf meer mest geproduceerd wordt dan op de beschikbare grond van het bedrijf mag worden uitgereden. De verplichting geldt voor een deel van het bedrijfsoverschot. Per regio zijn er wettelijke mestwerkingspercentages vastgesteld, die ieder jaar worden bijgesteld. In regio Oost, waar Ede en omringende gemeenten toe behoren, is het percentage voor 2017 vastgesteld op 52\% van het mestoverschot op bedrijfsniveau (uitgedrukt in kg fosfaat). In 2014 was dit percentage nog maar $15 \%$. Bedrijven in Ede dienen dit jaar dus ruim de helft van het bedrijfsoverschot te (laten) verwerken. Waar de mest verwerkt wordt, is niet regionaal gebonden. Dus de te verwerken mest uit de gemeente Ede mag overal in Nederland verwerkt worden.

Verwerken van mest kan op verschillende manieren, zoals het verbranden of vergassen van dierlijke meststoffen tot een as waarin maximaal $10 \%$ organische stof aanwezig is, het verwerken tot mestkorrels, gedroogd digestaat of het rechtstreeks exporteren naar het buitenland. Veehouders verwerken doorgaans niet zelf de mest, maar sluiten mestverwerkingsovereenkomsten af met mestverwerkers.

\section{Mestproductie in Ede}

De productie van mest en de mineralen stikstof en fosfaat in Ede en omringende gemeenten is een van de hoogste in ons land: in de gemeente Ede schommelt de stikstofproductie al jaren rond de 7 miljoen $\mathrm{kg}$ en fosfaatproductie rond de 3,5 miljoen $\mathrm{kg}$. In 2014 bedroeg het overschot in Ede 3,2 miljoen $\mathrm{kg}$ fosfaat ${ }^{1}$. Dit betekent dat in gemeente Ede $95 \%$ van de fosfaatproductie in mest niet op eigen grond kan worden aangewend. Het gaat met name om fosfaat in pluimvee-, varkens- en kalvermest, samen verantwoordelijk voor $86 \%$ van het overschot in Ede (zie Figuur S1).

\footnotetext{
${ }^{1}$ De overschotten drukken we uit in fosfaat, omdat dit momenteel de meest limiterende factor is voor het mestoverschot.
} 

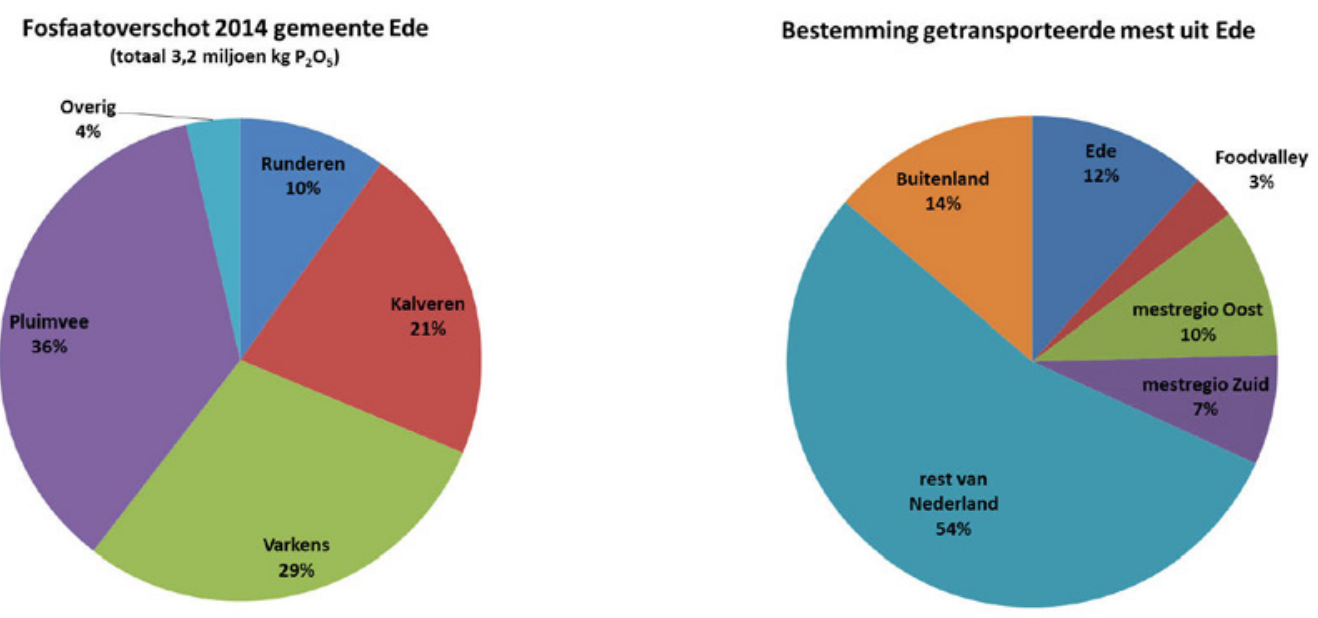

Figuur S1 Fosfaatoverschot en bestemming getransporteerde mest voor het jaar 2014 in de gemeente Ede (Bron: INITATOR en RVO, bewerking Wageningen Environmental Research).

Het merendeel van het mestoverschot van de veehouderijen in Ede wordt buiten de gemeente afgezet. Het gaat naar bedrijven die nog plaatsingsruimte voor mest hebben of de mest verwerken. Veel mest (54\%), met name varkens- en pluimveemest, wordt afgezet in regio's buiten de gebieden met veel veehouderij. Het gaat dan om de rest van Nederland, buiten de regio's Oost en Zuid. Verder wordt $14 \%$ van het overschot, met name pluimveemest, rechtstreeks naar het buitenland getransporteerd.

\section{Mestverwerkingsopgave in Ede}

In 2014, toen het verwerkingspercentage op $15 \%$ van het mestoverschot lag, kon ruimschoots voldaan worden aan de verwerkingsplicht. Veel werd gerealiseerd door de verwerking van pluimveemest (o.a. verbranding in BMC Moerdijk) (zie Figuur S2). Daar waar niet voldaan werd aan de mestverwerkingscapaciteit, zoals bij runderen, kalveren en varkens is waarschijnlijk de overgedragen mestverwerkingsplicht overgedragen aan andere bedrijven, zoals de pluimveehouders, en daarmee werd ook voor de verwerking van fosfaat in mest van andere diersoorten voldaan.

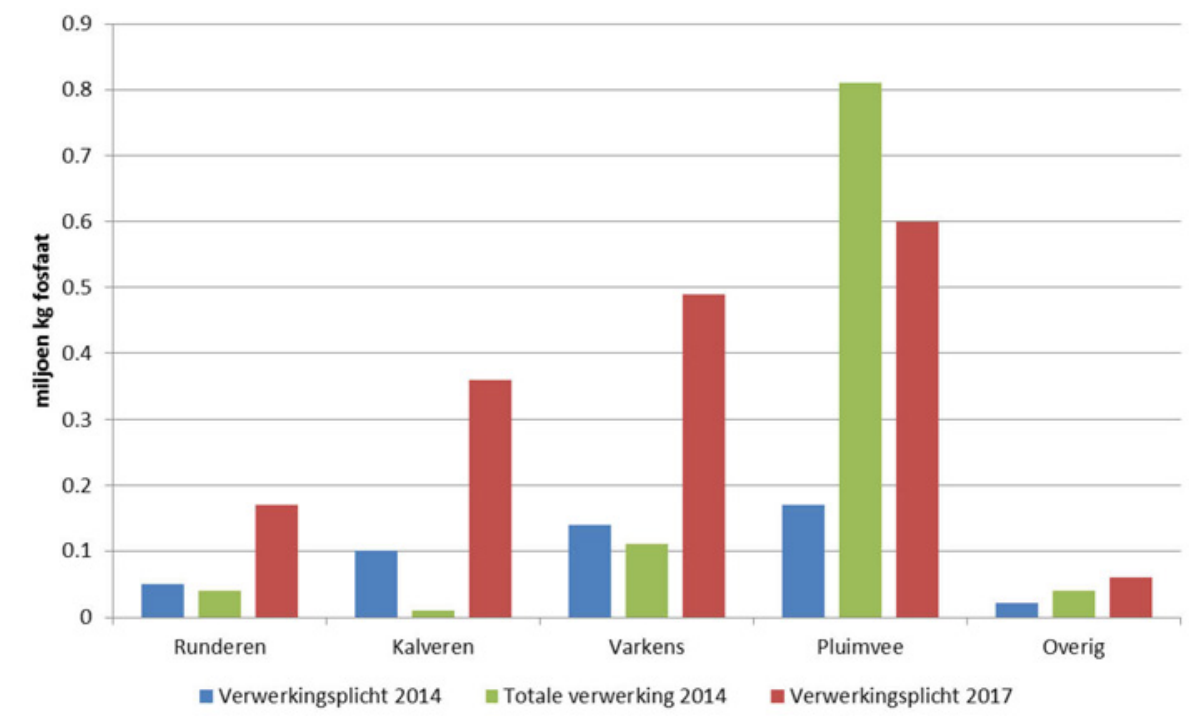

Figuur S2 Actuele mestververwerking in 2014 en de mestverwerkingsplicht in 2014 en 2017 in de gemeente Ede (Bron: INITATOR en RVO, bewerking Wageningen Environmental Research). 
De verwerkingsplicht voor het jaar 2017 is een stuk hoger (52\%). Ten opzichte van verwerking in 2014 dient er 0,7 miljoen $\mathrm{kg}$ fosfaat meer verwerkt te worden (uitgaande van een gelijkblijvende mestproductie). Bij pluimveemest is de verwerking waarschijnlijk nog steeds geen knelpunt. In 2014 werd er al meer verwerkt dan er in 2017 noodzakelijk is. De grootste opgave ligt bij bedrijven met kalveren of varkens.

\section{Beschikbare mestverwerkingscapaciteit}

Mest uit de gemeente Ede mag overal in Nederland verwerkt worden. In 2017 is de totale verwerkingsopgave in Nederland 37,1 miljoen kg fosfaat. Bureau Mestafzet inventariseert jaarlijks de verwerkingscapaciteit en maakt de inschatting dat in 2016 de totale operationele mestverwerkingscapaciteit in Nederland ergens tussen de 29,5 tot 36 miljoen kg fosfaat uitkomt. Veel van de huidige verwerkingscapaciteit zit in de regio Zuid $(12,7 \mathrm{~kg}$ miljoen fosfaat). Daarnaast verwerkt BMC Moerdijk veel pluimveemest ( $9,0 \mathrm{~kg}$ miljoen fosfaat) (ligt in regio Overig). In de regio Oost is de verwerkingscapaciteit nog gering (1,3 kg miljoen fosfaat). Aan uitbreiding van de verwerkingscapaciteit wordt gewerkt. Voor de regio Oost staat zelfs een vertienvoudiging van de huidige capaciteit gepland in de komende jaren ${ }^{2}$. Gezien de geplande uitbreidingen in Nederland is de verwachting dat er komende jaren voldoende capaciteit beschikbaar kan komen om aan de mestverwerkingsopgave te voldoen.

\section{Voldoende mestverwerkingscapaciteit is in het zicht, maar is nog niet vanzelfsprekend}

Hoewel er steeds meer mest verwerkt moet worden en er veel uitbreiding van mest-

verwerkingscapaciteit gepland is, komt (grootschalige) mestverwerking niet altijd van de grond. Daarvoor zijn verschillende oorzaken aan te wijzen, zoals de trage vergunningverlening, maatschappelijke weerstand, gebrek aan deelname door boeren, financiering en technische problemen. Als de capaciteit voor mestverwerking onvoldoende blijft, wordt export van mest steeds belangrijker. Afzet van dierlijke mest in het buitenland staat echter onder druk en wordt de komende jaren steeds lastiger. De regio's langs onze grenzen kampen namelijk zelf steeds meer met mestoverschotten waardoor de plaatsingsruimte beperkt is. Verder weg gelegen afzetgebieden zullen nodig zijn. Daarnaast hebben de melkveehouders in Nederland momenteel een uitzonderingspositie om hun grasland meer te bemesten dan de Europese vastgestelde gebruiksnorm (derogatie). Indien deze uitzonderingspositie komt te vervallen, wordt het mestoverschot in Nederland nog vele malen groter en zal er meer mest verwerkt moeten worden.

\section{Kansen voor verwaarding van mest; van kostenpost naar inkomsten}

Er zijn veel ontwikkelingen gaande die steeds meer inzetten op verdere verwaarding van dierlijke mest met kansen om veehouders te laten profiteren van deze waardevermeerdering. De komende jaren zal de techniek dat waardevolle meststoffen uit de dierlijke mest opgewerkt kunnen worden tot aparte fosfaat-, stikstof- en kaliproducten, zich steeds verder ontwikkelen. De producten vragen minder opslag en kunnen beter aansluiten bij de vraag vanuit binnen- en buitenland. Mineralenconcentraten kunnen in potentie ook als kunstmestvervanger dienen. Wel dienen deze mineralen uit dierlijke mest dan door Brussel te moeten worden erkend als kunstmestvervanger en dat is momenteel, m.u.v. een pilot, nog niet aan de orde.

Naast verwerking tot waardevolle grondstoffen voor afzet buiten het bedrijf zijn er ook ontwikkelingen waarbij mest als onderdeel van de kringloop op bedrijfs- of gebiedsniveau wordt opgenomen. Zo zijn Ecoferm (Uddel) en Kringloopboeren (Noord-Nederland) voorbeelden van landbouwsystemen waarin getracht wordt de emissies naar het milieu te reduceren door interne kringlopen te creëren.

\section{Mestverwerking in Ede: grootschalig of kleinschalig?}

Het ruimtelijk beleid van provincie Gelderland en gemeente Ede biedt de mogelijkheid om op boerderijniveau bedrijfseigen mest te verwerken. Indien verwerking grootschaliger wordt en er mest van meerdere bedrijven verwerkt wordt, is het niet zonder meer toegestaan. Vanwege de verkeersbewegingen, nuttige toepassing van de producten uit de verwerking (denk aan energie) en de landschappelijke en milieukundige effecten, wordt bij grootschalige mestverwerking de juiste

\footnotetext{
2 Het initiatief van Beukers op de Kievitsmeent in gemeente Ede maakt hier onderdeel van uit met een verwerkingscapaciteit van 230.000 ton mest met daarin, naar schatting, ca. 0,5 miljoen kg fosfaat.
} 
locatiekeuze steeds belangrijker. In gemeente Ede is grootschalige mestvergisting maatwerk via de mogelijkheid van een specifieke afwijking van het bestemmingsplan.

De ontwikkelingen in mestverwerking laten zien dat mestverwerking zowel kleinschalig als grootschalig kan plaatsvinden. Indien bedrijven groot genoeg zijn ( $>10.000 \mathrm{~m}^{3}$ mest) kan het aantrekkelijk zijn om dit op boerderijschaal te doen. Het is echter de verwachting dat met name op boerderijschaal wordt ingezet op het bewerken van mest met behulp van eenvoudige technieken, zoals het scheiden van dikke en dunne fractie, en dat verdere verwerking meer op een centrale, grootschalige manier zal plaatsvinden. Dit omdat dit complexere processen zijn die een bepaalde schaalgrootte vergen om tot een aantrekkelijke tarief voor verwerking te komen.

\section{Aanbevelingen mestverwerking Ede}

Veel mest uit Ede wordt elders verwerkt. Vooral voor varkens- en kalvermest is er een noodzaak voor meer verwerkingscapaciteit. Aangezien transport een deel van de verwerkingskosten bepaalt, kan het aantrekkelijk zijn om de mest op eigen bedrijf te scheiden en vervolgens in de eigen regio te laten verwerken. Daarvoor is meer centrale, grootschalige verwerkingscapaciteit nodig. Er zijn voldoende initiatieven die daarin kunnen voorzien, de vraag is echter of deze allemaal haalbaar zijn.

We doen daarom de volgende aanbevelingen voor de gemeente Ede en omringende gemeenten:

- Ondersteun mestverwerkingsinitiatieven met een haalbare businesscase en met regionaal draagvlak. Concreet betekent dit dat er voor deze initiatieven voldoende deelname van boeren uit de regio is en dat de initiatiefnemers in dialoog met de omgeving de plannen en ruimtelijke inpassing zodanig vormgegeven hebben dat de overlast voor de omgeving beperkt blijft.

- Bepaal als gemeente aan welke voorwaarden locaties moeten voldoen voor grootschalige mestverwerking. Maatwerk per initiatief is nodig, maar een nadere invulling van het huidige gemeentelijk beleid biedt duidelijkheid voor initiatiefnemers. Aangezien mestverwerking niet gebonden is aan de gemeentegrenzen, is afstemming in regionaal verband wenselijk.

- Creëer ruimte voor innovatie. Technieken en bedrijfsconcepten zijn sterk in ontwikkeling; verken met regionale bedrijven en agrarische ondernemers op welke manier ze hieraan bij kunnen dragen en wat daarvoor nodig is. Denk aan het faciliteren van ondernemers, ruimte bieden in regelgeving, fysieke ruimte bieden in ruimtelijke ordening en het creëren van lerende netwerken met verschillende stakeholders. 


\section{$1 \quad$ Inleiding}

\subsection{Probleemstelling}

Het gebruik van dierlijke mest is wettelijk beperkt, omdat te veel meststoffen in grond- en oppervlaktewater terechtkomen. Veehouders moeten daarom een deel van de mest die overblijft (mestoverschot), laten verwerken. Zo kunnen zij er korrels van laten maken en die in het buitenland verkopen. Of er energie mee opwekken door de mest te verbranden. De wijziging van de Meststoffenwet die de verplichte mestverwerking regelt, is per 2014 ingegaan. Voor de mestverwerkingsplicht is mestverwerkingscapaciteit nodig.

De gemeente Ede neemt een positieve grondhouding aan ten opzichte van initiatieven die bijdragen aan (een deel van) de oplossing van de mestproblematiek in de gemeente en de regio, temeer omdat ze belang hechten aan een vitale agrarische sector in de gemeente. Zo is de gemeente Ede al geruime tijd in gesprek met een partij die in Ede een mestverwerkingsinstallatie nabij Kievitsmeent wil realiseren. Het initiatief is uiteraard binnen de gemeente Ede ambtelijk en bestuurlijk besproken. Naast een positieve grondhouding leidde dat ook tot vragen over de mestproblematiek binnen de gemeente en de regio op een ander schaalniveau: Welke opgave ligt er op gemeentelijk en regionaal niveau en wat zijn daarvoor de beste oplossingen?

Dit leidde tot de volgende vragen die in dit rapport nader zijn uitgewerkt en beantwoord:

a. Maak inzichtelijk welke regionale en lokale mestverwerkingsopgave er ligt en formuleer oplossingsrichtingen voor die opgave, rekening houdend met het mest(verwerkings)beleid van Rijk en provincie;

b. Onderzoek welke type locaties mogelijk zijn voor mestverwerking, inclusief de vraag of dat grootschalig of kleinschalig opgezet moet (of kan) worden.

De gemeente vindt dat het initiatief mestverwerking Kievitsmeent (College van B\&W gemeente Ede, zaaknummer 11790, 2014) op dit moment nog steeds perspectief biedt. De gemeente stelt zich echter wel op het standpunt dat voor het verdere proces belangrijk is om meer zicht te krijgen op de genoemde vragen over mestverwerking in zijn algemeenheid alvorens stappen gezet kunnen worden met de mestverwerkingsinstallatie Kievitsmeent. De uitkomsten van dit onderzoek kunnen daarmee ook richting geven aan het onderzoeken van de kansrijkheid, omvang, breedte van het initiatief in combinatie met de verkenning van een gebiedsontwikkeling ter plekke.

\subsection{Projectdoelstelling}

Het doel van deze studie is het in beeld brengen van de huidige regionale en lokale wettelijke mestverwerkingsopgave van de gemeente Ede en omgeving. Specifieker gaat het hierbij:

- Op regionaal schaalniveau in beeld brengen wat de omvang van de mestverwerkingsopgave is: nu en in de toekomst; onderzoek ook wat de rol van de regio/gemeente zou moeten zijn bij de opgave nu en in de toekomst, rekening houdend met het mest(verwerkings)beleid van Rijk en provincie Gelderland;

- Op ditzelfde schaalniveau in beeld brengen welke initiatieven er zijn op het vlak van mestverwerking (inclusief uitrijden van mest) en mestvergisting en in welke fase deze verkeren nu en in de toekomst;

- Een analyse opstellen van vraag en aanbod in de mestverwerkingsbusiness;

- Vaststellen welke opgave er derhalve ligt in zowel regionaal verband als voor de gemeente Ede;

- Uitwerken hoe die opgave concreet kan worden geregeld: denk hierbij onder andere aan aantal voorzieningen, omvang en locatie(s);

- Beoordelen op welke wijze het actuele initiatief op Kievitsmeent past in de regionale en lokale opgave. 


\subsection{Onderzoeksaanpak}

De onderzoeksaanpak bestaat uit een kwantitatieve data-analyse, aangevuld en gecombineerd met een documentenanalyse en expert-knowledge binnen Wageningen University \& Research en regionale kennis van agrarische sector en het mestvraagstuk.

\section{De kwantitatieve data-analyse}

De omvang mestverwerkingsopgave voor de gemeente Ede en omgeving wordt gekwantificeerd op basis van modelberekening m.b.v. het model INITIATOR ${ }^{3}$, waarbij rekening wordt gehouden met het huidige beleid. Het model INITIATOR werkt op het niveau van zogenaamde STONE-plots (identieke combinaties van bodem en bodemgebruik op basis van informatie in $250 \mathrm{~m} \times 250 \mathrm{~m}$ cellen). INITIATOR heeft een directe koppeling met de GIAB-database (geografische informatie agrarische bedrijven) waardoor de locatie, de omvang van de veestapel, het kunstmestgebruik en het staltype bekend zijn voor alle bedrijven binnen een gewenste regio. Gebruikmakend van de wettelijke gebruiksnormen, mestverwerkingsplicht en bemestingsadviezen berekent INITIATOR de mestproductie, mestgebruiksruimte, mestverwerkingsopgave en mesttransport voor de gemeente Ede en omgeving (zie Bijlage 1 voor meer detail).

Daarnaast wordt gebruikgemaakt van data van de Rijksdienst voor Ondernemend Nederland (RVO) met betrekking tot de Vervoerbewijzen Dierlijke Meststoffen (VDM) (met o.a. getransporteerde hoeveelheid mest en laad- en loslocaties). Deze data worden gekoppeld aan de locaties in de regio en geven daarmee een beeld van de transporten van de mest ten behoeve van zowel direct aanwenden van de mest elders (a.g.v. mestoverschot) als het verwerken van mest en afzet buiten de sector of buitenland (a.g.v. mestverwerkingsplicht).

\section{Documentenanalyse}

Voor het inzichtelijk maken van de omvang van de mestverwerkingscapaciteit maken we gebruik van gegevens die Bureau Mest Afzet (BMA). Zij inventariseren samen met het Projectbureau Lokale Mestverwerking de mestverwerkingscapaciteit. De bedoeling is dat mestverwerkers de huidige en de verwachte capaciteit opgeven. In 2016 is de laatste inventarisatie uitgevoerd (www.bureaumestafzet.nl).

Daarnaast hebben we beleidsdocumenten en verordeningen van het Rijk, provincie en gemeente geanalyseerd.

\section{Expertmeeting}

De resultaten uit de kwantitatieve en kwalitatieve analyse zijn in een expertmeeting op maandag 7 januari 2017 besproken met een aantal deskundigen van de gemeenten, provincie, Omgevingsdienst, agrarische sector en mestmarkt (zie Bijlage 2 voor lijst met deelnemers). De kracht van de samenwerking in deze werksessie lag in het samenbrengen van data, beleidskennis, kennis van mest verwerken en het uitgebreide netwerk in de agrarische sector en het bediscussiëren van de resultaten en de rol van iedere partij in dezen. Van deze expertmeeting is geen integraal verslag gemaakt, maar de uitkomsten zijn verwerkt in deze rapportage (o.a. paragraaf 5.2).

\footnotetext{
3 http://www.wur.nl/nl/show/INITIATOR.htm.
} 


\section{Mestbeleid}

\subsection{Meststoffenwet}

De Meststoffenwet heeft tot doel het bevorderen van de deugdelijkheid van meststoffen en om de verontreiniging van bodem, grond- en oppervlaktewater door stikstof en fosfaat als gevolg van het gebruik van meststoffen te beperken.

\section{Gebruiksnormen en gebruiksruimte}

Belangrijk onderdeel van de Meststoffenwet zijn de regels over het gebruik van meststoffen. Voor het bemesten van landbouwgrond gelden maximumhoeveelheden stikstof, fosfaat en dierlijke mest. Hoeveel van elk soort gebruikt mag worden, hangt af van de hoeveelheid grond op bedrijfsniveau, de grondsoort en wat erop wordt verbouwd. Door voortschrijdende normstelling daalt het wettelijk toegestane gebruik van dierlijke mest. Bedrijven kunnen daarop reageren door mineralenarmer voer te gebruiken, minder dieren te houden of een groter deel van de mestproductie af te voeren.

\section{Afvoeren overschot}

Om aan de wettelijke normen te kunnen voldoen, voeren bedrijven die te veel mest produceren dit overschot af. Dit gebeurt naar bedrijven die nog plaatsingsruimte hebben om de mest te gebruiken, naar mestverwerkingsbedrijven en naar het buitenland. Daarnaast wordt een klein deel van de mest afgezet bij hobbyboeren en particulieren. De getransporteerde mest wordt uitgedrukt in hoeveelheden stikstof (exclusief gasvormige verliezen uit stal en opslag) en fosfaat.

Ruim de helft van de in Nederland door landbouwbedrijven in dierlijke mest afgevoerde stikstof en fosfaat wordt getransporteerd naar andere Nederlandse landbouwbedrijven. De rest van de afgevoerde mest wordt verwerkt (peiljaar 2013, Compendium voor de Leefomgeving, 2015).

\section{Derogatie en fosfaatplafond}

Derogatie is de uitzonderingspositie voor melkveehouders om hun grasland meer te bemesten dan de Europese vastgestelde gebruiksnorm. Een aantal regio's, waaronder Nederland, mag in plaats van $170 \mathrm{~kg}$ onder bepaalde voorwaarde 230 of $250 \mathrm{~kg}$ stikstof uit dierlijke mest per hectare per jaar gebruiken. Dat mag, omdat op deze plekken het grasland een hogere opbrengst heeft en er door het gematigde klimaat meer stikstof in de lucht verdwijnt. Om te voorkomen dat de druk op de mestmarkt onverantwoord groot wordt, heeft de Europese Unie een fosfaatplafond voor Nederland ingesteld: dit is een harde voorwaarde voor Nederland om derogatie te krijgen. Het fosfaatplafond is de maximale fosfaatproductie van de veestapel in Nederland. Het fosfaatplafond is gelijkgesteld aan de fosfaatproductie van de Nederlandse veestapel in 2002 en bedraagt 172,9 miljoen $\mathrm{kg}$ fosfaat.

In december 2016 rapporteerde het CBS dat het fosfaatplafond voor de tweede keer op rij werd overschreden. Hoewel in 2016 de productie vergeleken met een jaar eerder daalde met bijna 2 procent (van 180,1 tot 177 miljoen $\mathrm{kg}$ ), was dat nog steeds ruim 4 miljoen $\mathrm{kg}$ boven het plafond van 172,9 miljoen $\mathrm{kg}$ (zie Figuur 1). De daling van de fosfaatproductie is in vrijwel de hele veehouderij zichtbaar, behalve in de melkveehouderij, waar na het afschaffen van het melkquotum groei heeft plaatsgevonden. 


$\begin{array}{rr}x \mathrm{mln} \mathrm{kg} & x \mathrm{mln} \mathrm{kg} \\ 300 \quad & 300\end{array}$
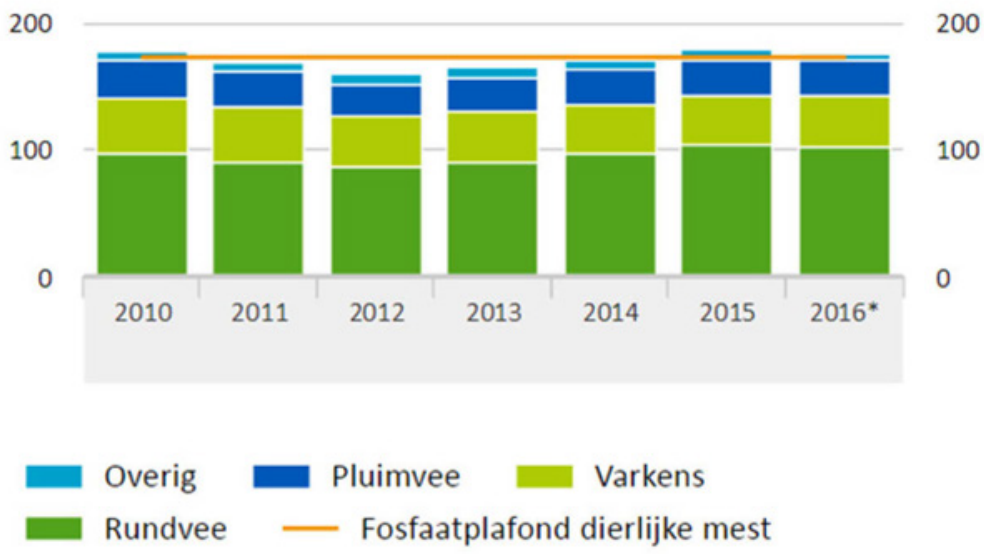

Figuur 1 Fosfaatproductie (in miljoen $\mathrm{kg}$ fosfaat) in dierlijke mest (CBS, 2016).

Momenteel wordt er hard gewerkt om de fosfaatproductie in de melkveehouderij te reduceren om te voorkomen dat de Europese Unie de derogatie intrekt of niet verlengt. De zuivelsector heeft samen met het ministerie van EZ in december 2016 een maatregelenpakket voor fosfaatreductie gepresenteerd. Deze is recentelijk omgezet in een ministeriële regeling (brief TK Maatregelenpakket fosfaatreductie 2017, 3 februari 2017). De maatregelen voorzien in de reductie van (op jaarbasis) 8,2 miljoen $\mathrm{kg}$ fosfaat door de melkveehouderij. Dat is naar de huidige inzichten voldoende om in 2017 onder het fosfaatplafond te komen. Het pakket bestaat uit: (1) fosfaatreductie via voerspoor, die naar verwachting een reductie oplevert van 1,7 miljoen kilogram fosfaat; (2) de bedrijfsbeëindigersen krimpregeling en (3) het Fosfaatreductieplan ZuivelNL. De laatste twee onderdelen leveren samen naar schatting 6,5 miljoen $\mathrm{kg}$ fosfaatreductie op (www.zuivelnl.org).

De derogatie is daarmee tot het eind 2017 veiliggesteld. Het wegvallen van derogatie betekent dat er nog minder dierlijke mest kan worden aangewend en er meer mestverwerking nodig is. Wageningen Economic Research becijferde in maart 2016 dat het wegvallen van derogatie betekent dat er $75 \%$ meer mestverwerkingscapaciteit nodig is en de verwerking zal moeten toenemen tot circa 41 miljoen $\mathrm{kg}$ fosfaat per jaar (Koeijer et al. 2016). Als de benodigde mestverwerkingscapaciteit op het moment van het eventueel verlies van derogatie niet beschikbaar is, zal het aantal koeien moeten verminderen. Op basis van de dieraantallen van 2013 is dan een reductie van $20 \%$ van het aantal graasdieren nodig.

\subsection{Mest verwerken en mestverwerkingsplicht}

Dierlijke meststoffen verwerken

Veehouders moeten een deel van de mest die op het bedrijf is geproduceerd laten verwerken. Op deze manier wil het ministerie van Economische Zaken de druk op de gebruiksnormen voor mest verminderen en werken aan een duurzaam evenwicht tussen mestproductie en mestafzet. Veehouders regelen dit door mestverwerkingsovereenkomsten af te sluiten met mestverwerkers.

De Meststoffenwet en de Uitvoeringsregeling Meststoffenwet verstaan onder dierlijke meststoffen verwerken (EZ, 2014, 2016a, b): het behandelen van dierlijke meststoffen tot een eindproduct, waarbij het gaat om:

- Het verbranden of vergassen van dierlijke meststoffen tot een as waarin maximaal $10 \%$ organische stof aanwezig is;

- Het verwerken van dierlijke meststoffen tot mestkorrels; 
- Mengsel van gedroogd digestaat en verwerkt categorie 1-materiaal, bedoeld in artikel 8 van verordening (EG) nr. 1069/2009 (EC, 2009);

- Exporteren van dierlijke meststoffen.

NB De Meststoffenwet heeft het dus over het verwerken van dierlijke mest als het 'buiten de markt voor mest wordt gehouden'. In het kader van Besluit Omgevingsrecht (Bor) spreekt men over verwerken als de mest met technieken wordt toegepast die de aard en hoedanigheid van mest veranderen, zoals vergisten of composteren van mest. Vergisten van mest is een bewerkingsmethode onder de Meststoffenwet en valt niet onder mestverwerking. Digestaat, het restproduct bij vergisting, dient daarvoor verder verwerkt te worden.

Het uiteindelijke doel van mestverwerking is het afzetten van dierlijke mest buiten de Nederlandse landbouwsector. De bedrijven hebben vier opties om aan de mestverwerkingsplicht te voldoen (zie Figuur 2):

- VDM: Vervoersbewijs Dierlijke Meststoffen (RVO-code 61)

Groene lijnen: mest wordt rechtstreeks vervoerd naar een verwerker.

- DPO: Drie Partijen Overeenkomst:

Oranje lijnen: mest wordt vervoerd naar een bewerker (mestbehandelaar), die het vervolgens vervoert naar een verwerker.

- OMP: Overgedragen MestverwerkingsPlicht (RVO-code 71)

Blauwe lijnen: de verwerkingsplicht wordt door een andere landbouwer overgenomen ${ }^{4}$.

- DEB: Rechtstreekse afzet in het buitenland (dit is een aparte categorie in de RVO data, RVO-codes 11-19)

Zwarte lijnen: mest wordt rechtstreeks vervoerd naar buitenland.

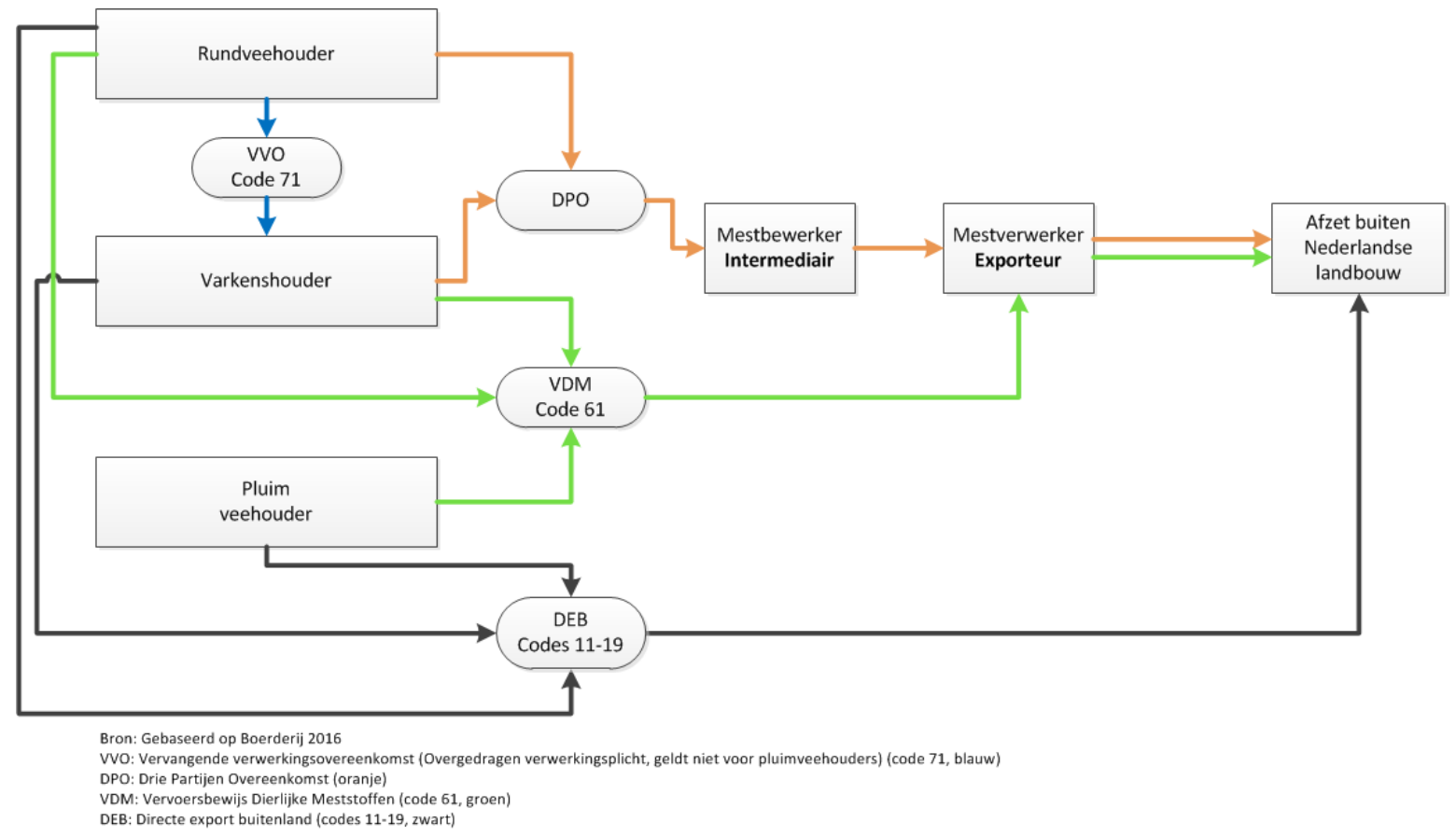

Figuur 2 Overzicht van opties om aan mestverwerkingsplicht te voldoen.

\footnotetext{
4 Met betrekking tot de overgedragen mestverwerkingsplicht, ofwel de afvoer van mest naar een landbouwbedrijf, gelden de volgende voorwaarden:

- Het bedrijf dat de mest afneemt, ligt hemelsbreed maximaal $20 \mathrm{~km}$ vanaf uw productielocatie (let wel: deze beperking geldt niet voor de overige opties van mestverwerking, die mogen overal plaatsvinden).

- De afnemer mag de mest niet eerst opslaan, maar gebruikt deze direct op zijn landbouwgrond.

- Het totale bedrijfsoverschot dient afgevoerd/overgedragen te worden.

- Het bedrijfsoverschot is maximaal $25 \%$ van de totale mestproductie.
} 


\section{Mestverwerkingsplicht}

De verplichting om mest te laten verwerken, geldt alleen als er op het agrarische bedrijf meer mest geproduceerd wordt dan op de beschikbare grond van het bedrijf mag worden uitgereden. In Tabel 1 staan de wettelijke mestwerkingspercentages weergegeven en de totale benodigde verplichte mestverwerkingscapaciteit. De verwerkingspercentages gelden per bedrijf. Dus ieder bedrijf met een overschot zal een deel van het bedrijfsoverschot moeten (laten) verwerken. De rest van het bedrijfsoverschot wordt afgevoerd naar bedrijven met plaatsingsruimte. Waar de mest verwerkt wordt, is niet regionaal gebonden. Dus de te verwerken mest in de gemeente Ede mag overal in Nederland verwerkt worden.

Het verwerkingspercentage hangt af van de regio waarin het agrarische bedrijf ligt en verschilt per jaar. De percentages worden jaarlijks vastgesteld door de rijksoverheid (Van Dam, 2016), welke zijn gebaseerd op het advies van de Commissie Deskundigen Meststoffenwet (Oenema, 2016). In gebieden waar het mestoverschot hoger is, ligt het verwerkingspercentage hoger.

Tabel 1 Percentages verplichte mestverwerking van het bedrijfsoverschot per regio en de totale verplichte mestverwerkingscapaciteit. ${ }^{1)}$

\begin{tabular}{lllll} 
Jaar & Oost & Overig & $\begin{array}{l}\text { Totale verplichte } \\
\text { mestverwerking }\end{array}$ \\
\hline 2014 & $30 \%$ & $15 \%$ & $5 \%$ & 17,0 \\
\hline 2015 & $50 \%$ & $30 \%$ & $10 \%$ & $28,0-29,7$ \\
\hline 2016 & $55 \%$ & $35 \%$ & $10 \%$ & 32,8 \\
\hline 2017 & $59 \%$ & $52 \%$ & $10 \%$ & 37,1 \\
\hline
\end{tabular}

1) De in 2016 door de CDM geadviseerde cijfers, welke door de staatsecretaris zijn overgenomen Oenema (2016); Van Dam (2016).

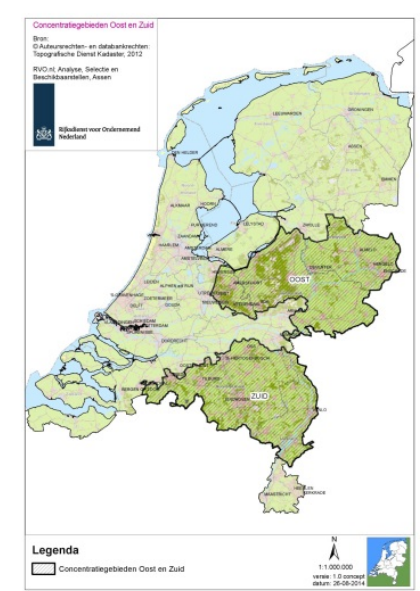




\section{Aard en omvang mestproblematiek in gemeente Ede en omgeving}

\subsection{Veehouderij in gemeente Ede en omringende gemeenten}

In de gemeente Ede (en omringende gemeenten behorende tot Food Valley) komt veel veehouderij voor die veel mest produceert. Met name de hokdierhouderij, zoals varkens, pluimvee en kalveren, komt relatief veel voor. Figuur 3 geeft de relatieve ontwikkeling van het aantal dieren per diersoort over de afgelopen jaren ten opzichte van peiljaar 2010. De CBS-statistieken laten zien dat sinds 2010 in de regio:

- het aantal dieren in de pluimveehouderij stabiel blijft; ${ }^{5}$

- er een lichte groei $(10 \%)$ is van melkkoeien en vleeskalveren;

- het aantal dieren in de varkenshouderij daalt (20 tot $30 \%$ ).

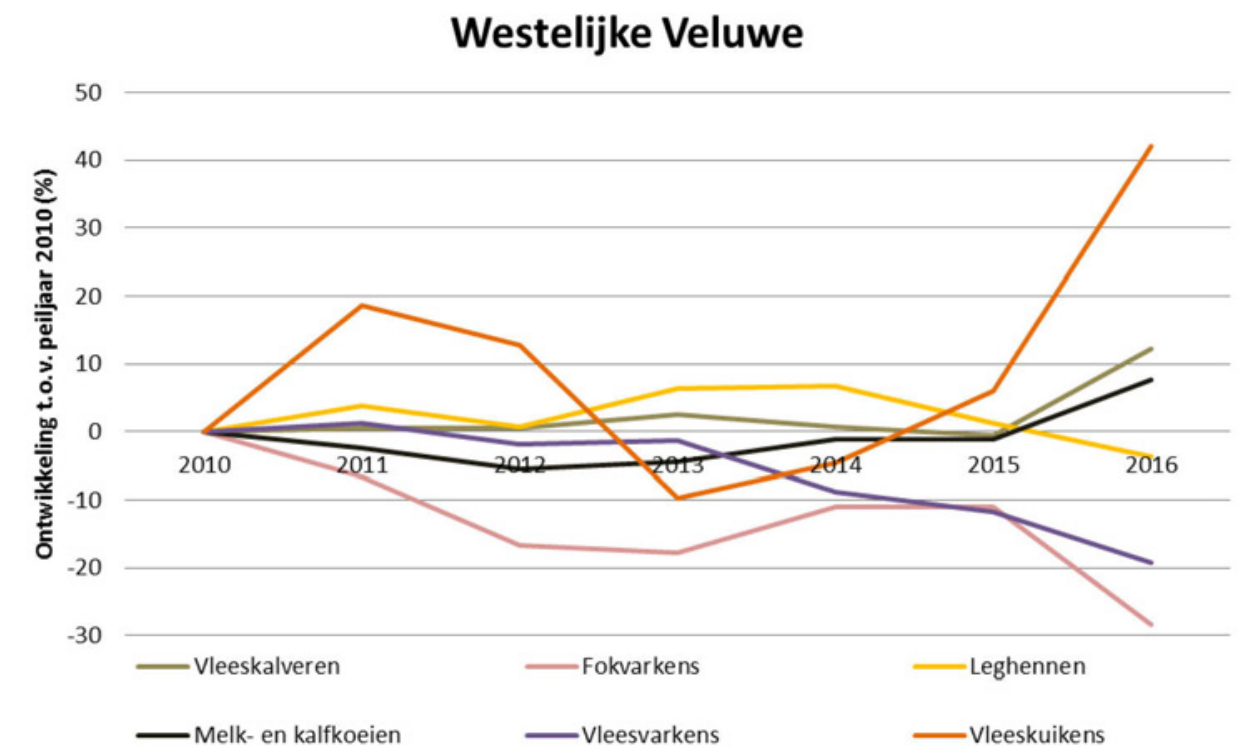

Figuur 3 Relatieve ontwikkeling van de dieraantallen in landbouwgebied Westelijke Veluwe (jaar 2010 = 100), (CBS Statline, 2016).

\footnotetext{
${ }^{5}$ Sterke wisseling in aantal vleeskuikens per jaar heeft te maken met snelle doorlooptijd van deze dieren op de bedrijven; daardoor kunnen de stallen weleens leeg staan bij het moment van registreren van het aantal dieren.
} 


\subsection{Mestproductie}

De productie van mest en de mineralen stikstof en fosfaat in Ede en omringende gemeenten is een van de hoogste in ons land. In de gemeente Ede schommelt de stikstofproductie al jaren rond de 7 miljoen $\mathrm{kg}$ en de fosfaatproductie rond de 3,5 miljoen $\mathrm{kg}$.

Figuur 4 geeft een landelijk beeld van de stikstof- en fosfaatproductie in Nederland. De regionale verschillen zijn groot. De productie is het grootst in gebieden met veel intensieve veehouderij: het oostelijk deel van Noord-Brabant, Noord-Limburg, de Achterhoek en Twente en de westelijke Veluwe. In dit laatste gebied ligt de gemeente Ede en is de stikstofproductie meer dan $700 \mathrm{~kg} \mathrm{~N} / \mathrm{ha}$ en de fosfaatproductie is ruim $320 \mathrm{~kg} P /$ ha.

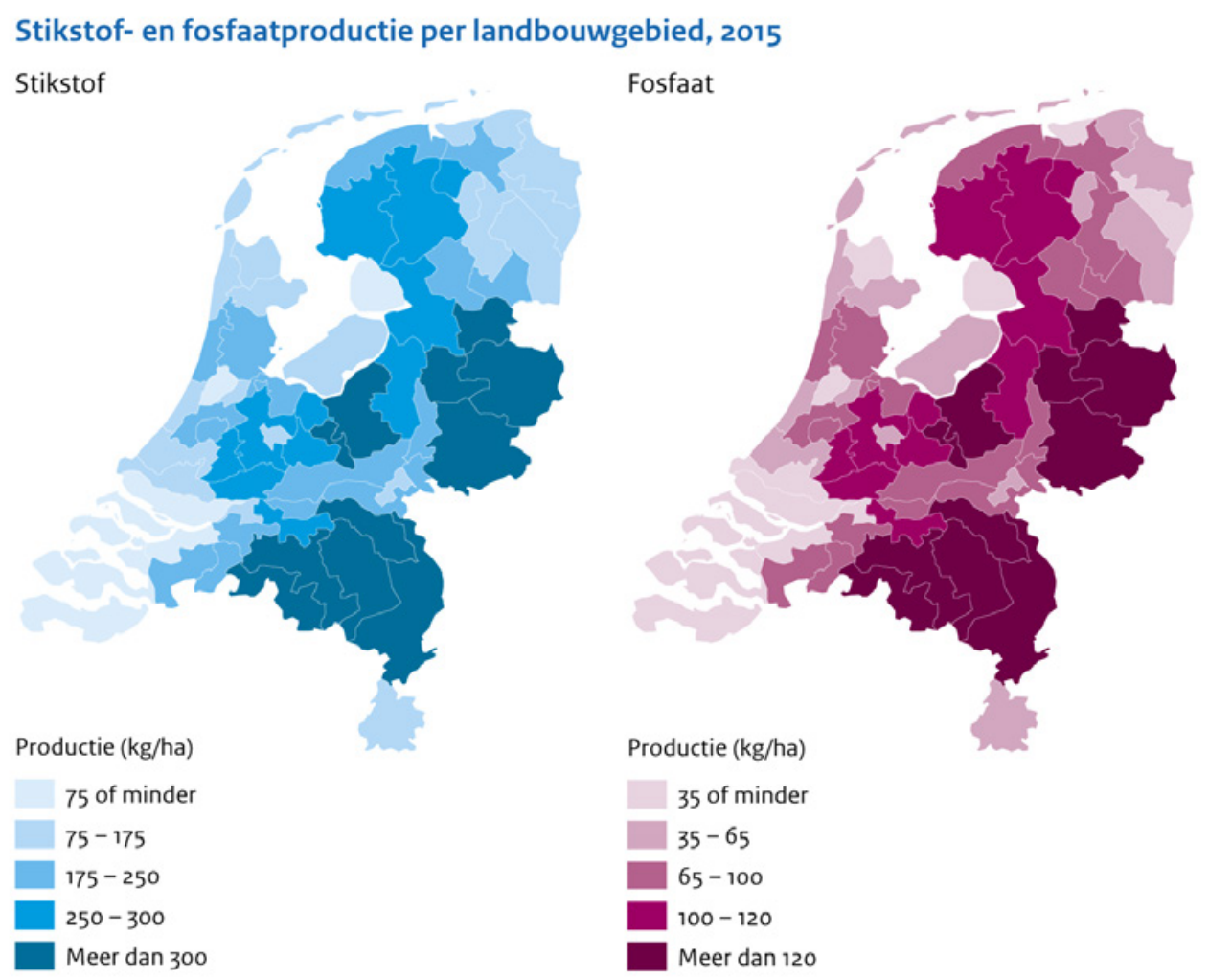

Bron: CBS

Figuur 4 Stikstof-en fosfaatproductie per landbouwgebied, 2015 (bron: CBS, bewerking Compendium voor de leefomgeving, 2016).

In de volgende alinea's staan de met INITIATOR berekende mestproductie en -overschotten voor respectievelijk de gemeente Ede, regio Food Valley en de mestregio Oost-Nederland weergegeven. De overschotten drukken we uit in fosfaat, omdat dit momenteel de meest limiterende factor is voor het mestoverschot. De onderliggende data zijn gegeven in Bijlage 3. 


\section{Gemeente Ede}

De mestproductie in de gemeente Ede bedroeg in $20143,4 \mathrm{mln} \mathrm{kg}$ fosfaat, hoofdzakelijk in pluimvee-, varkens- en kalverenmest. Het fosfaatoverschot in Ede bedroeg in 2014 3,2 mln kg fosfaat. Dat wil zeggen dat in de gemeente Ede $95 \%$ van de productie fosfaat in mest niet op eigen grond kan worden aangewend.

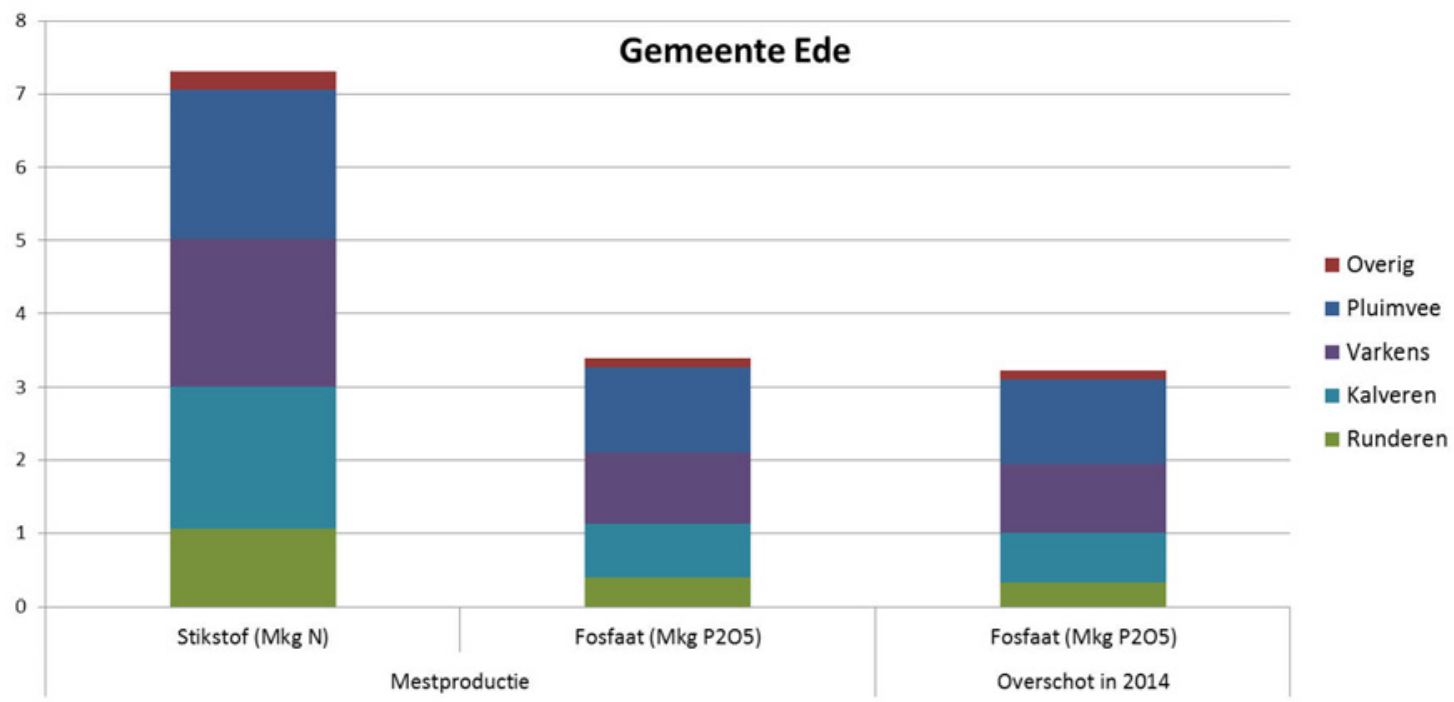

Figuur 5 Berekende mestproductie en -overschot in Ede, peiljaar 2014 (Bron: Initiator, Wageningen Environmental Research).

\section{Food Valley}

De mestproductie in de Food Valley-gemeenten bedroeg in 2014 8,4 mln kg fosfaat, ook hier hoofdzakelijk door pluimvee-, varkens- en kalverenmest. Het fosfaatoverschot in de regio Food Valley bedroeg in 2014 7,7 mln kg fosfaat. Dat wil zeggen dat in regio Food Valley $92 \%$ van de productie fosfaat in mest niet op eigen grond kan worden toegediend.

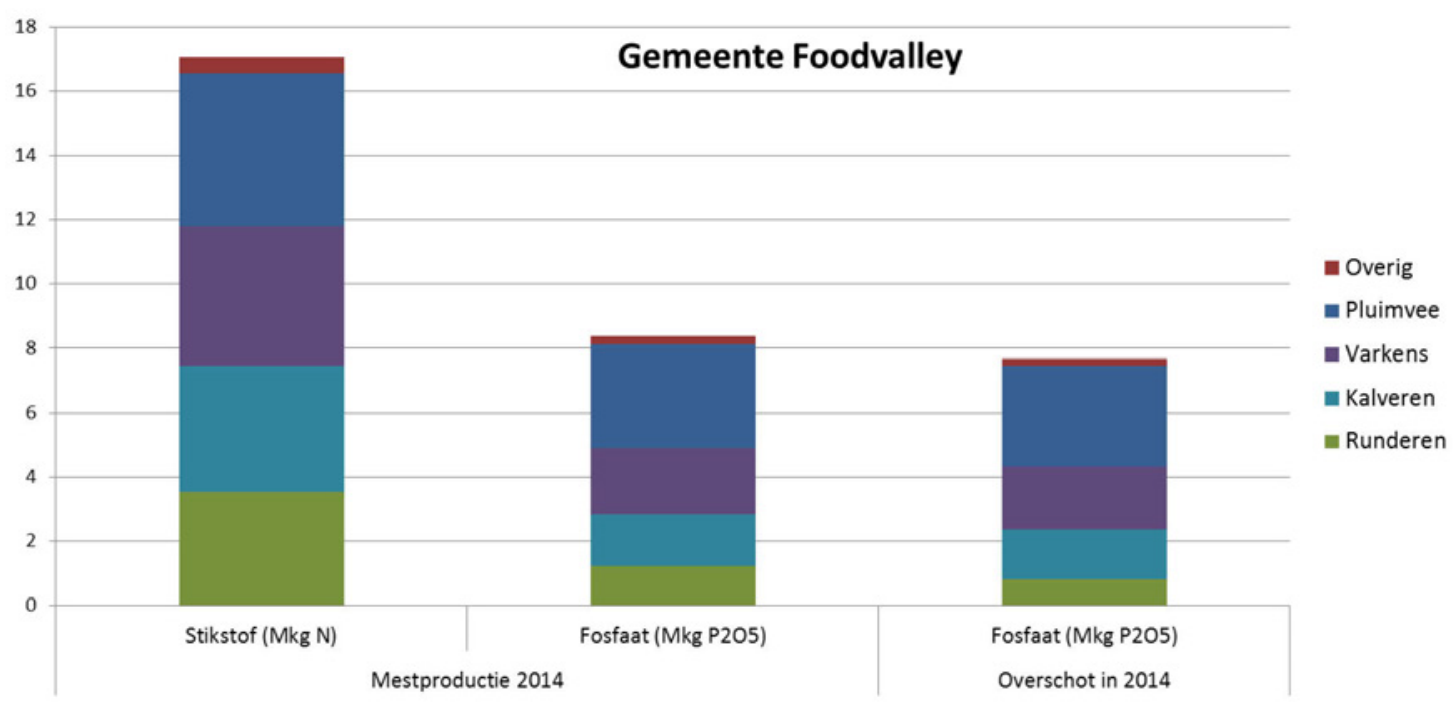

Figuur 6 Berekende mestproductie en -overschot in de regio Food Valley, peiljaar 2014 (Bron: Initiator, Wageningen Environmental Research). 


\section{Oost-Nederland}

De mestproductie in de regio Oost-Nederland bedroeg in $201441 \mathrm{mln} \mathrm{kg}$ fosfaat, waarvan $70 \%$ (29 $\mathrm{mln} \mathrm{kg} \mathrm{fosfaat)} \mathrm{bestaat} \mathrm{uit} \mathrm{runder-} \mathrm{en} \mathrm{varkensmest.} \mathrm{Op} \mathrm{de} \mathrm{schaal} \mathrm{van} \mathrm{Oost-Nederland} \mathrm{is} \mathrm{eveneens}$ sprake van een mestoverschot, zij het beduidend geringer dan op het niveau van de Food Valleygemeenten. Het fosfaatoverschot in Oost-Nederland bedroeg in $201430 \mathrm{mln} \mathrm{kg}$ fosfaat, dit betreft $74 \%$ van de productie.

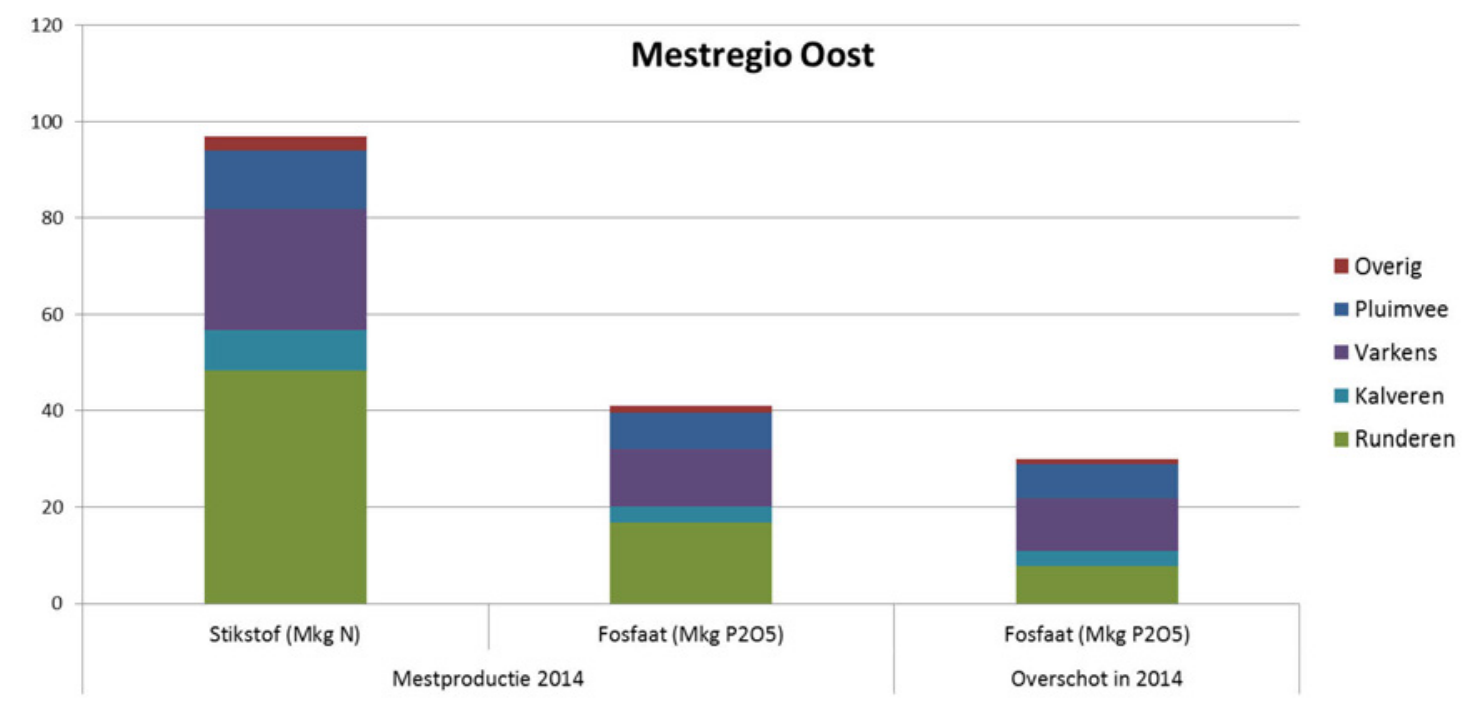

Figuur 7 Berekende mestproductie en -overschot in de mestregio Oost-Nederland, peiljaar 2014 (Initiator, Wageningen Environmental Research).

\subsection{Mesttransport}

De mestoverschotten in Ede en omringende gemeenten worden getransporteerd naar andere regio's waar plaatsingsruimte is of waar mestbehandelaren of -verwerkers gevestigd zijn. Daarnaast wordt er ook mest aangevoerd van buiten het gebied. Voor Ede en omringende gemeenten gaat het hierbij voornamelijk om kalvermest, waarvoor waarschijnlijk driepartijenovereenkomsten (DPO, zie Figuur 2) zijn afgesloten.

In de volgende alinea's is de omvang van de getransporteerde mest voor respectievelijk de gemeente Ede, regio Food Valley en de regio Oost-Nederland weergegeven. De onderliggende data zijn gegeven in Bijlage 3.

\section{Gemeente Ede}

Vanuit Ede werd er in $2014 \mathrm{ca} .4 \mathrm{mln}$ kg fosfaat getransporteerd, ofwel ca. $98 \%$ van wat er in Ede wordt geproduceerd en aangevoerd. Van de getransporteerde mest wordt ca. 0,5 m/n kg fosfaat $(12 \%)$ weer in Ede afgezet. Het resterende deel, 3,5 mln kg fosfaat, wordt buiten Ede afgezet. Dit komt nagenoeg overeen met het berekende mestoverschot in Ede (zie par. 3.2). Meer dan de helft (54\%) van de getransporteerde mest wordt buiten de mestregio's Oost en Zuid afgezet in de rest van Nederland (Overig). Een relatief groot deel van de getransporteerde pluimveemest $(0,5 \mathrm{mln} \mathrm{kg}$ fosfaat, ofwel $32 \%$ ) wordt rechtstreeks in het buitenland afgezet (DEB, zie Figuur 2). 


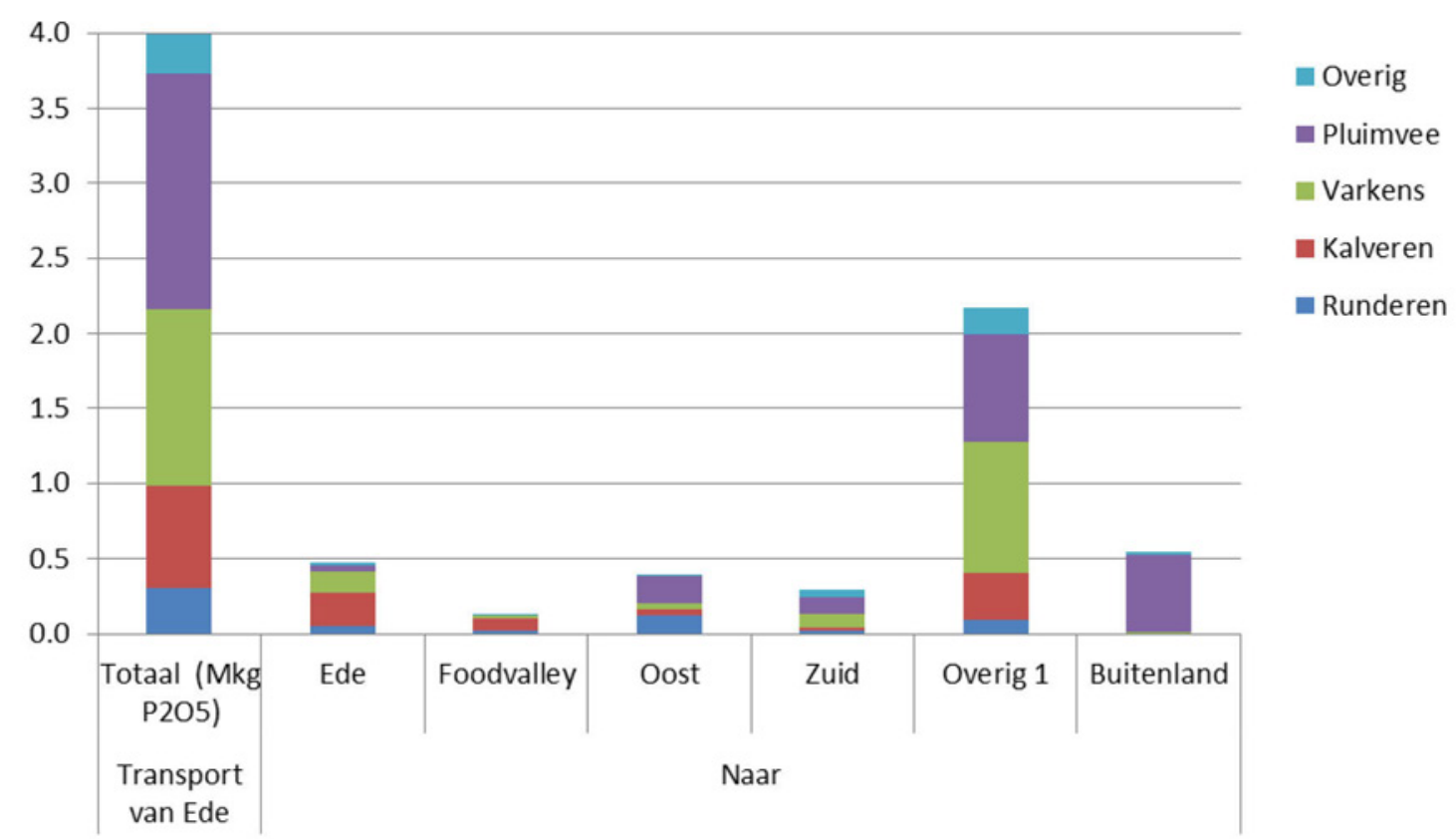

Figuur 8 Geregistreerde hoeveelheid fosfaat in mesttransporten Ede in 2014 (Bron: RVO, bewerking Wageningen Environmental Research, 2016).

Getoond is de hoeveel mest (in miljoen $\mathrm{kg}$ fosfaat) die vanuit de gemeente Ede wordt getransporteerd en de bestemming van de getransporteerde mest.

Food Valley

Vanuit de regio Food Valley werd er in 2014 ca $8 \mathrm{mln} \mathrm{kg} \mathrm{fosfaat} \mathrm{getransporteerd,} \mathrm{ofwel} \mathrm{ca.} \mathrm{95 \%} \mathrm{van}$ wat er in de regio Food Valley wordt geproduceerd en aangevoerd. Van de getransporteerde mest wordt ruim 14\% (1,1 mln kg fosfaat) weer in de regio Food Valley (Ede + Food Valley) afgezet. De helft van de getransporteerde mest (3,9 mln $\mathrm{kg}$ fosfaat) wordt buiten de mestregio's Oost en Zuid afgezet in de rest van de Nederland (Overig). Een relatief groot deel van de getransporteerde pluimveemest $(1,4 \mathrm{mln} \mathrm{kg}$ fosfaat, ofwel $14 \%)$ wordt rechtstreeks in het buitenland afgezet (DEB, zie Figuur 2).

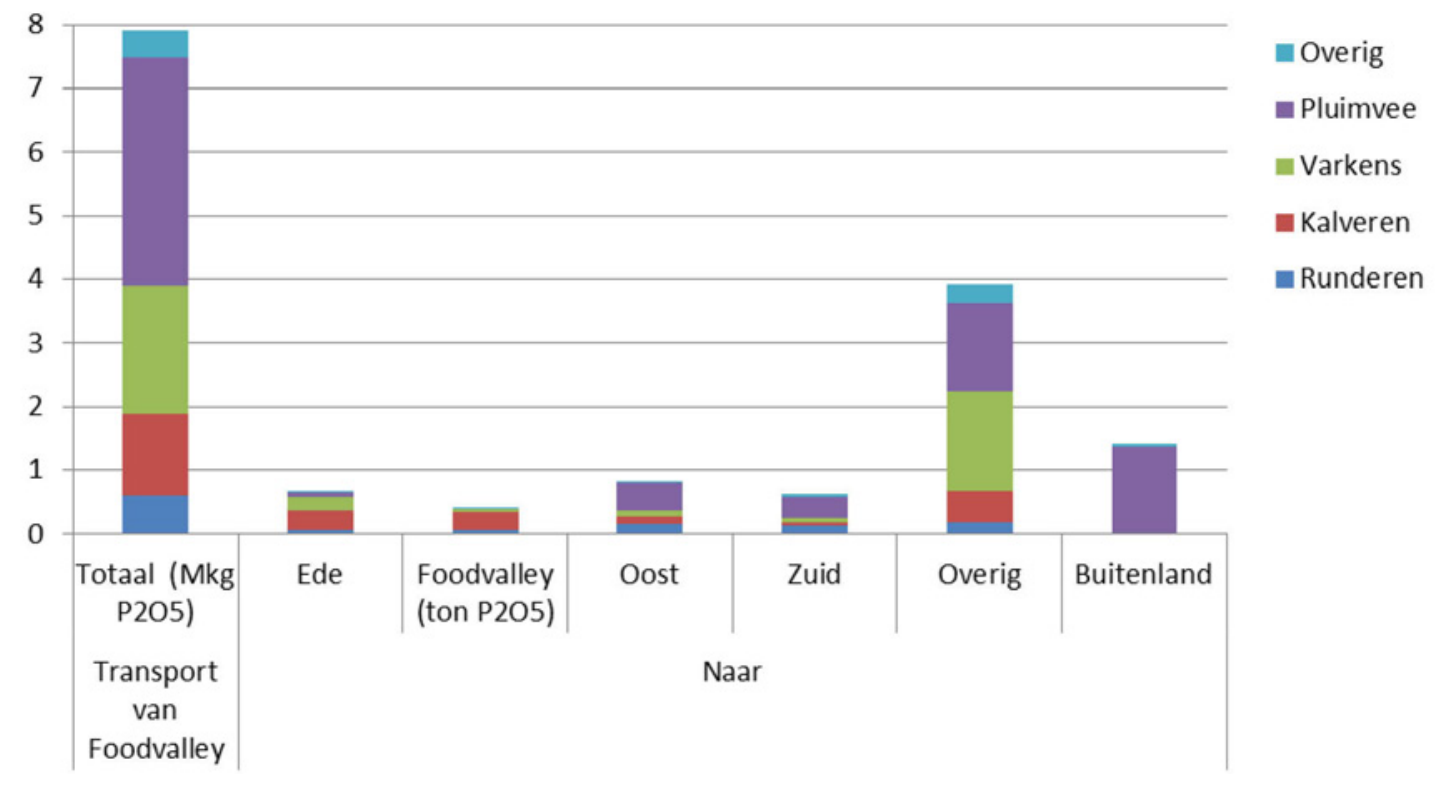

Figuur 9 Geregistreerde hoeveelheid fosfat in mesttransporten in de regio Food Valley in 2014 (Bron: RVO, bewerking Wageningen Environmental Research, 2016).

Getoond is de hoeveel mest (in miljoen $\mathrm{kg}$ fosfaat) die vanuit de regio Food Valley wordt getransporteerd en de bestemming van de getransporteerde mest. 


\section{Oost-Nederland}

In de regio Oost-Nederland werd er in $2014 \mathrm{ca}$. $25 \mathrm{mln} \mathrm{kg} \mathrm{fosfaat} \mathrm{getransporteerd,} \mathrm{ofwel} \mathrm{ca.} 61 \%$ van wat er in Oost-Nederland wordt geproduceerd en aangevoerd (Figuur 10). Ruim 30\% (7,5 mln kg fosfaat) blijft in regio Oost (totaal van Ede, Food Valley en Oost). Bijna de helft van de getransporteerde mest (12 mln kg fosfaat) gaat naar de rest van Nederland, particulieren en onbekend (Overig).

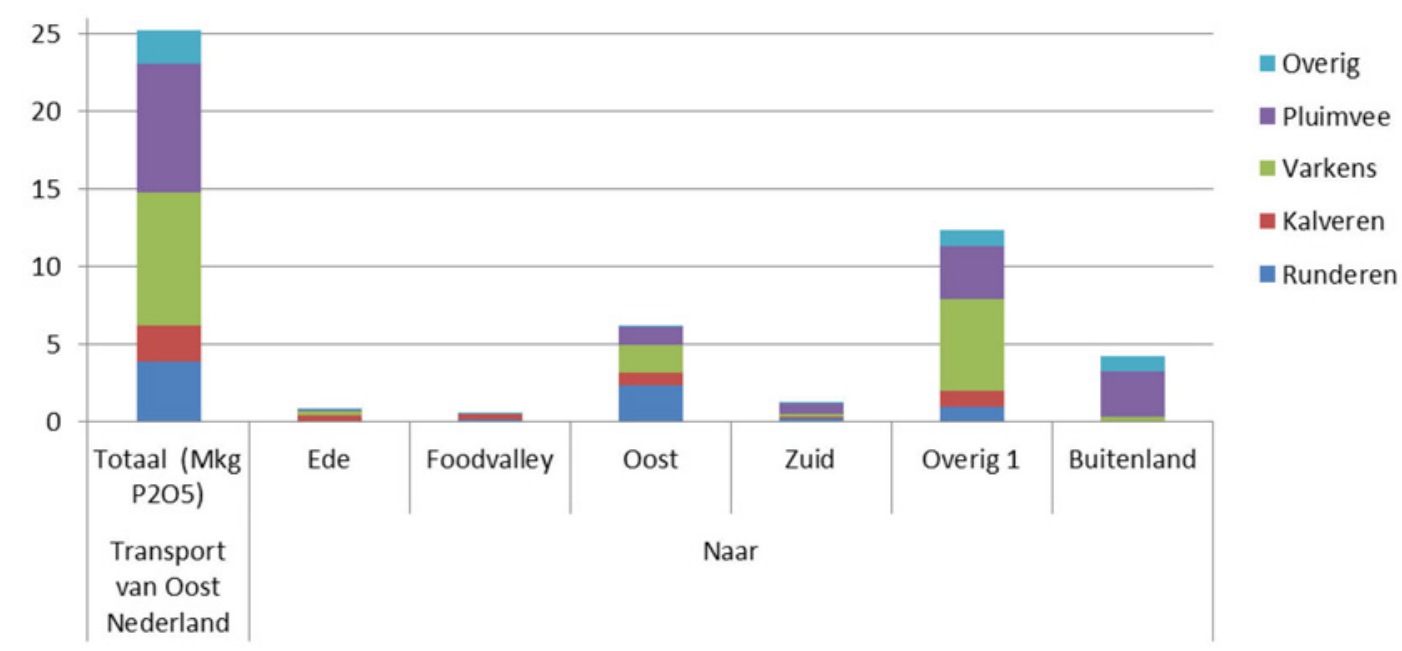

Figuur 10 Geregistreerde hoeveelheid fosfaat in mesttransporten regio Oost-Nederland in 2014 (Bron: RVO, bewerking Wageningen Environmental Research, 2016).

Getoond is de hoeveel mest (in miljoen $\mathrm{kg}$ fosfaat) die vanuit de regio Oost-Nederland wordt getransporteerd en de bestemming van de getransporteerde mest.

\subsection{Mestverwerking}

Een deel van het mestoverschot wordt verwerkt. In onderstaande alinea's staan de berekende verwerkingsplicht en de geregistreerde, voor verwerking getransporteerde hoeveelheden mest voor respectievelijk de gemeente Ede, de regio Food Valley en de regio Oost-Nederland weergegeven. De onderliggende data zijn gegeven in Bijlage 3.

\section{Gemeente Ede}

Voor de gemeente Ede werd in 2014 ruimschoots voldaan aan de verwerkingsplicht. Er werd 2 keer meer verwerkt dan de verplichte hoeveelheid. Dit werd voornamelijk gerealiseerd door extra verwerking van pluimveemest. Uitgaande van de verwerkingsplicht voor het jaar 2017 wordt, gebaseerd op de productie en verwerking in 2014, niet voldaan aan de verwerkingsplicht. Om aan de verwerkingsplicht van 2017 te voldoen, dient nog ca. 0,7 mln kg fosfaat extra verwerkt te worden. 


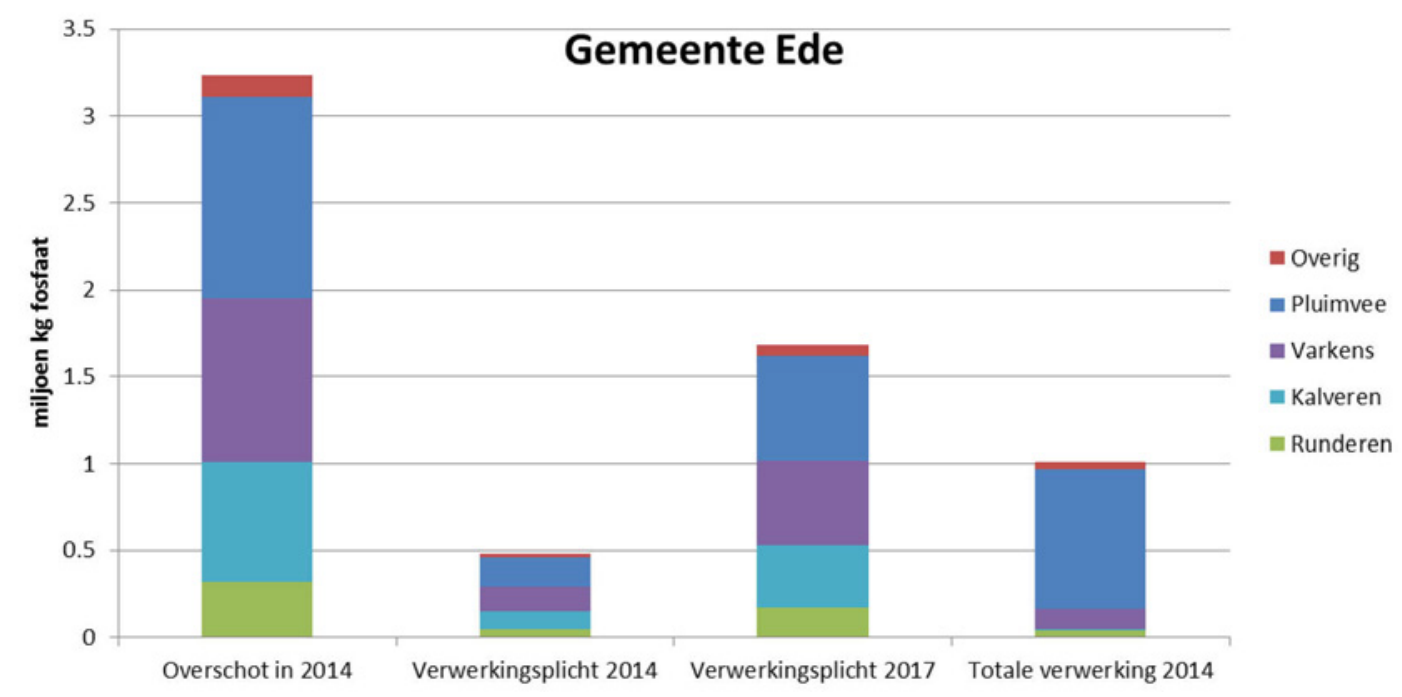

Figuur 11 Berekende mestoverschot in Ede in 2014, de verwerkingsplicht in 2014 en 2017 (beide op basis van het overschot in 2014) en de geregistreerde verwerkte hoeveelheid mest op basis van de vervoersovereenkomsten van RVO in 2014 (in miljoen $\mathrm{kg}$ fosfaat). De totale verwerking betreft de som van VDM en DEB (zie Figuur 2).

Food Valley

Voor de regio Food Valley werd in 2014 ruimschoots voldaan aan de verwerkingsplicht. Dit werd echter vnl. gerealiseerd door de verwerking van pluimveemest. Uitgaande van de verwerkingsplicht voor het jaar 2017 wordt, gebaseerd op de productie en verwerking in 2014, niet voldaan aan de verwerkingsplicht. Om aan de verwerkingsplicht van 2017 te voldoen, dient nog ca. 1,65 mln kg fosfaat verwerkt te worden.

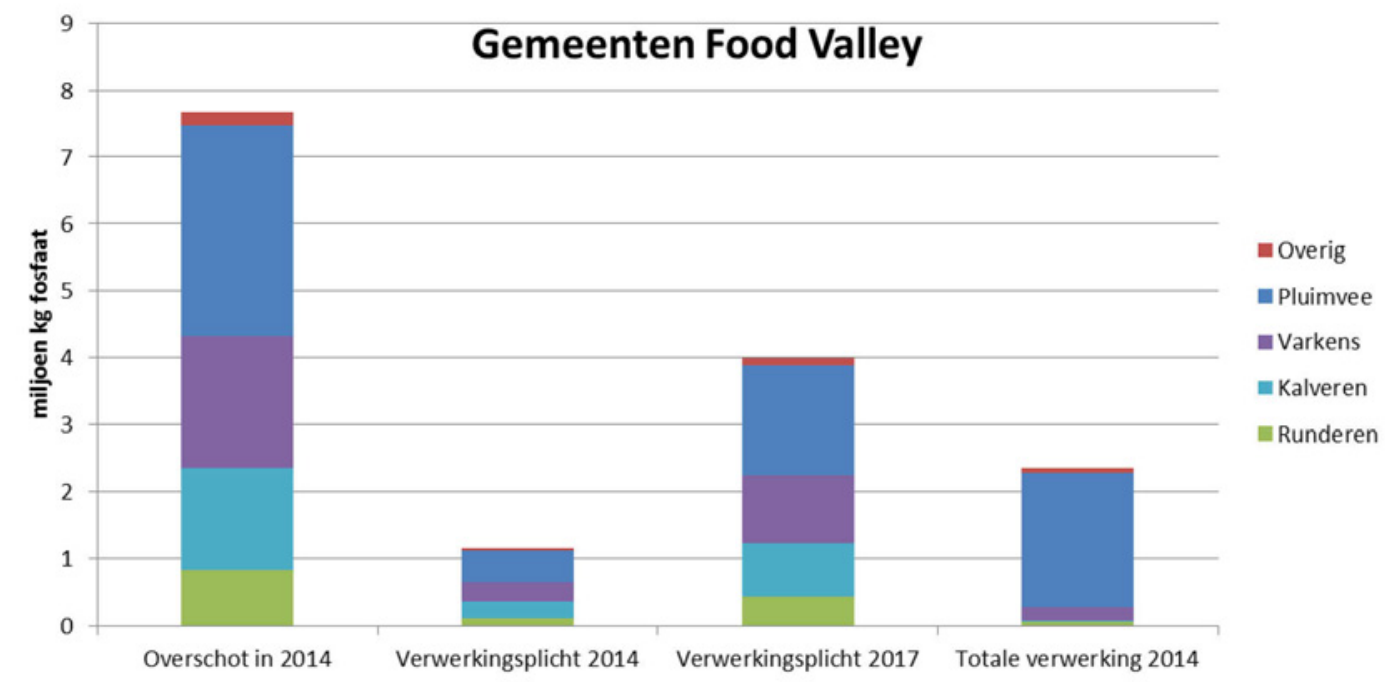

Figuur 12 Berekende mestproductie in de regio Food Valley in 2014, de verwerkingsplicht in 2014 en 2017 (beide op basis van het overschot in 2014) en de geregistreerde verwerkte hoeveelheid mest op basis van de vervoersovereenkomsten van RVO in 2014 (in miljoen $\mathrm{kg}$ fosfaat). De totale verwerking betreft de som van VDM en DEB (zie Figuur 2).

\section{Oost-Nederland}

Voor de regio Oost-Nederland werd in 2014 voldaan aan de verwerkingsplicht. Dit werd echter vnl. gerealiseerd door de verwerking van pluimveemest. Voor een groot gedeelte van de gemeenten in Oost-Nederland is er sprake van een flinke toename van de verwerkingsplicht in 2017 (zie Figuur 12). Gebaseerd op de productie en verwerking in 2014 , dient er nog 8,8 miljoen fosfaat extra verwerkt te worden. 


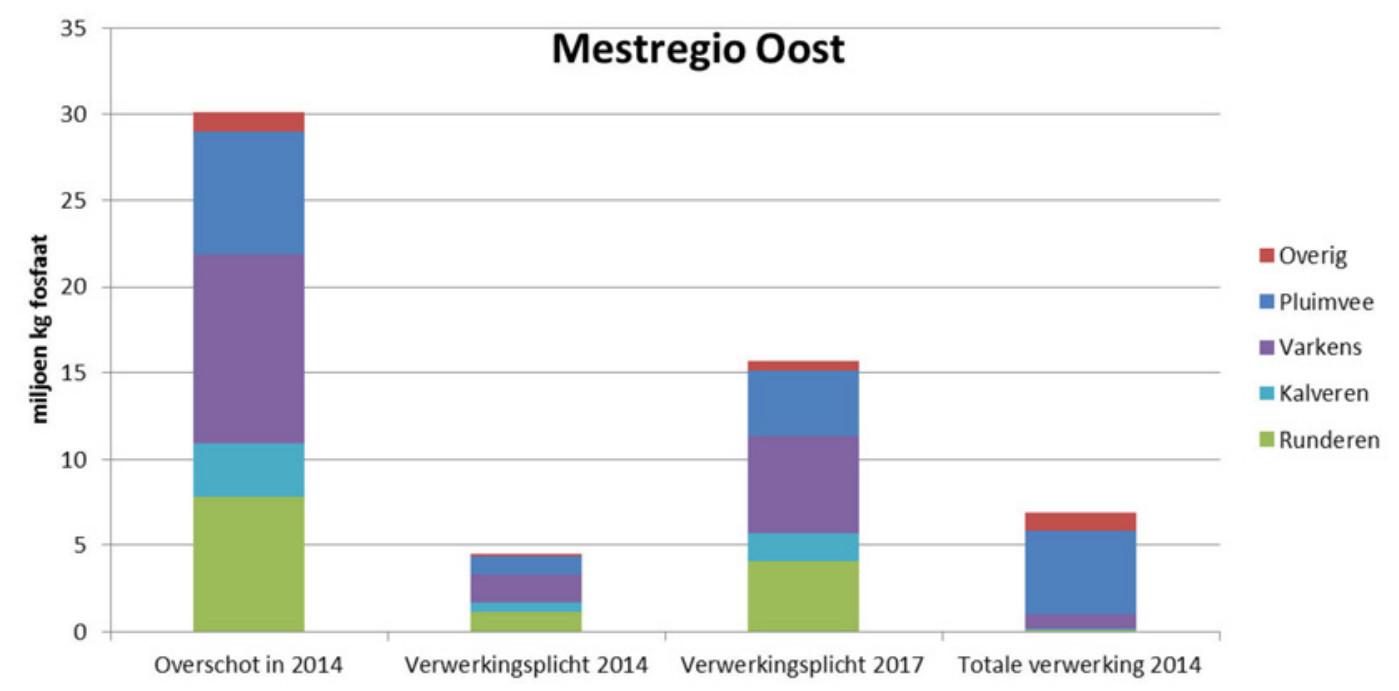

Figuur 13 Berekende mestproductie in de regio Oost-Nederland in 2014, de verwerkingsplicht in 2014 en 2017 (beide op basis van het overschot in 2014) en de geregistreerde verwerkte hoeveelheid mest op basis van de vervoersovereenkomsten van RVO in 2014 (in miljoen $\mathrm{kg}$ fosfaat). De totale verwerking betreft de som van VDM en DEB (zie Figuur 2).
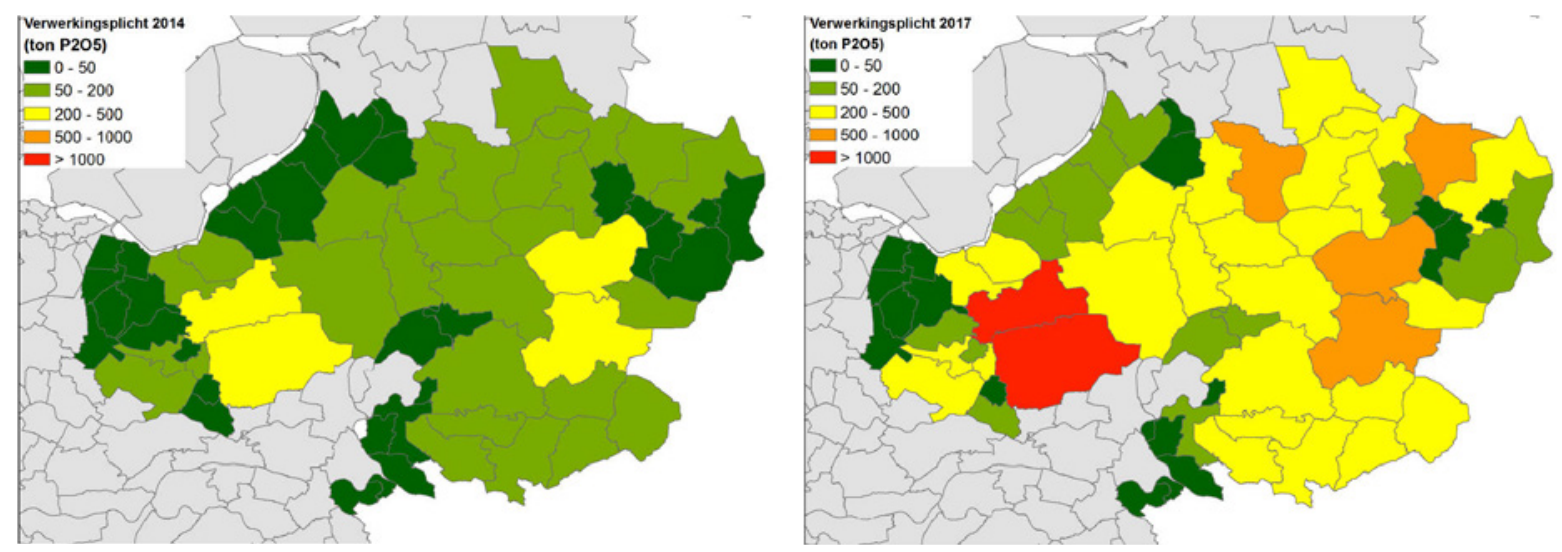

Figuur 14 Berekende mestverwerkingsplicht in 2014 (15\%) en de verwachte mestverwerkingsplicht in 2017 (52\%) (onder) per gemeente in mestregio Oost, uitgedrukt in ton P/gemeente voor het jaar 2014 (bron: Initiator, Wageningen Environmental Research).

\subsection{Mestverwerkingscapaciteit}

Geïnventariseerde operationele mestverwerkingscapaciteit

Bureau Mest Afzet en het Mestverwerkingsloket hebben in 2014 en 2015 middels een digitale enquête een landelijke inventarisatie uitgevoerd onder (potentiële) mestverwerkers naar de mestverwerkingscapaciteit in Nederland over de jaren 2013, 2014, 2015 en 2016 (BMA, 2015, 2016). In deze inventarisaties wordt onder 'mestverwerkingscapaciteit' verstaan de hoeveelheid fosfaat die door een initiatiefnemer zelf is geëxporteerd, verbrand of tot mestkorrels is verwerkt. Daarmee voldoet de 'mestverwerkingscapaciteit' aan de definitie van dierlijke meststoffen verwerken van de Meststoffenwet. In deze inventarisaties is de rechtstreekse export naar het buitenland van onbewerkte mestsoorten niet meegenomen, maar deze vorm van export valt wel onder de definitie van dierlijke meststoffen verwerken van de Meststoffenwet. De uitgevoerde inventarisaties geven een goede benadering maar geen volledig beeld, omdat niet alle mestverwerkers (volledige) informatie hebben aangeleverd. 
Tabel 2 Mestverwerkingscapaciteit ${ }^{1)}$ van respondenten met een operationele installatie, verdeeld

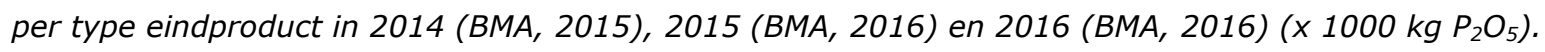

\begin{tabular}{|c|c|c|c|}
\hline Jaar & 2014 & 2015 & 2016 \\
\hline Aantal respondenten & 67 & 60 & 69 \\
\hline Mestkorrels met $90 \%$ ds. & 1.653 & 5.880 & 6.450 \\
\hline Gehygiëniseerde dikke fractie mest & 555 & 0.757 & 1.335 \\
\hline Gehygiëniseerde drijfmest & 240 & 1.676 & 1.340 \\
\hline Gehygiëniseerde dikke fractie digestaat & 1.207 & 0.889 & 0.541 \\
\hline Onbehandelde drijfmest & 0 & 0.025 & 0.035 \\
\hline Onbehandelde dikke fractie mest & 15 & & 0.123 \\
\hline Gedroogde mest & 25 & & 0.013 \\
\hline Totaal & 16.832 & 25.284 & 29.527 \\
\hline
\end{tabular}

1) De mestverwerkingscapaciteit is in de rapportage gedefinieerd als de hoeveelheid fosfaat die door een initiatiefnemer zelf is geëxporteerd, verbrand of tot mestkorrels is verwerkt. Deze hoeveelheid is afkomstig van de eindschakels in de keten. Daarmee voldoet de 'Mestverwerkingscapaciteit' volgens de auteurs aan de definitie van mestverwerking van de Meststoffenwet (Verkerk et al. 2015).

Tabel 2 laat zien dat de meeste fosfaat verwerkt wordt door verbranding tot as (pluimveemest), mestkorrels en compost. Daarnaast wordt veel mest, al dan niet behandeld, gehygiëniseerd en dan geëxporteerd.

Tabel 3 geeft een indruk van de verdeling van de operationele mestverwerkingscapaciteit per gebied in Nederland ${ }^{6}$. Hieruit blijkt dat de mestverwerkingscapaciteit in de regio Oost (waartoe Ede behoort) een stuk lager is dan die in de regio Zuid en Overig. In het gebied Overig is de mestverwerkingscapaciteit het grootst vanwege de aanwezigheid van de pluimveemestverbrandingscentrale BMC Moerdijk, welke goed is voor circa 9 miljoen $\mathrm{kg}$ fosfaat verwerkingscapaciteit per jaar.

Tabel 3 Operationele mestverwerkingscapaciteit per gebied in 2016 (in miljoen $\mathrm{kg}$ fosfaat) (Bron: $B M A, 2016)$.

\begin{tabular}{|c|c|}
\hline Mestregio & Mestverwerkingscapaciteit (miljoen kg fosfaat) \\
\hline Concentratiegebied Zuid & 12.7 \\
\hline Concentratiegebied Oost & 1.3 \\
\hline Waarvan verbranding pluimveemest & $9.0^{1)}$ \\
\hline Totaal & 29.5 \\
\hline
\end{tabular}

1) Betreft vrijwel volledig BMC Moerdijk. De capaciteit van BMC bedraagt 450000 ton pluimveemest. Uitgaande van $19 \mathrm{~kg}$ fosfaat per ton pluimveemest (op basis van Initiator i.c.m. WUM) wordt dan bij BMC 8.6 miljoen kg fosfaat.

Het bleek echter niet mogelijk om op basis van de openbaar beschikbare data van BMA af te leiden wat de capaciteit in Ede betrof. In verband met privacygevoeligheid stelt BMA geen informatie op gemeenteniveau beschikbaar. Wel publiceert BMA een overzicht van bedrijven met verwerkingscapaciteit van bedrijven die aangegeven dat hun gegevens openbaar gemaakt mogen worden

(http://www.bureaumestafzet.nl/home/?_overlay=\%211090384\%2Fdms\%2Fdetail\%3Fid\%3D9202). Op deze lijst staan echter geen bedrijven die in Ede gevestigd zijn.

\footnotetext{
${ }^{6}$ De informatie m.b.t. capaciteit mestverwerking is enkel op het niveau van mestregio's beschikbaar en niet op gemeenteniveau.
} 


\section{Schatting operationele mestverwerkingscapaciteit}

Door Verkerk et al. (2016) is over 2016 een inschatting gemaakt van de mestverwerkingscapaciteit bij de niet-respondenten op basis van een inventarisatie middels een enquête. Deze bijdrage van installaties die niet op de enquête hebben gereageerd en de verwerkingscapaciteit in ontwikkeling bedroeg in 2016 6,5 miljoen kg fosfaat (Verkerk et al. 2016), waardoor de inschatting van de totale operationele mestverwerkingscapaciteit over 2016 op 36 miljoen kg fosfaat uitkomt.

\section{Geplande extra mestverwerkingscapaciteit}

Verkerk et al. (2016) geven ook een inschatting van de geplande extra mestverwerkingscapaciteit per jaar (2016, 2017 en 2018 ev) per regio (zie Tabel 4). Hieruit blijkt dat voor de komende jaren (i.i.g. $\mathrm{t} / \mathrm{m}$ 2018) er voor de regio Oost een uitbreiding is gepland van bijna 10 miljoen $\mathrm{kg}$ fosfaat. Indien alle plannen gerealiseerd worden betekent dit bijna een vertienvoudiging van de huidige mestverwerkingscapaciteit in Oost. Het initiatief op de Kievitsmeent zal hier ook in verwerkt zijn en deze zal naar verwachting 0,5 miljoen $\mathrm{kg}$ fosfaat verwerken en ongeveer $5 \%$ aandeel hebben in de in Oost geplande verwerkingscapaciteit.

De geplande extra capaciteit in gebied Zuid is het grootst. In dit gebied is het percentage verwerkingsplicht het hoogst (55\% van het overschot op bedrijfsniveau in 2016). De ontwikkeling van extra verwerkingscapaciteit in gebied Overig is het kleinst.

Tabel 4 Geplande extra mestverwerkingscapaciteit over 2016 2016, 2017 en 2018 per regio (in miljoen $\mathrm{kg}$ fosfaat) (Bron: BMA, 2016).

\begin{tabular}{lccc} 
Regio & Nieuwe installaties & Uitbreidingen bestaand & Totaal per regio \\
Concentratiegebied Zuid & 7,5 & 6,9 & 14,4 \\
\hline Concentratiegebied Oost & 8,5 & 1,4 & 9,9 \\
\hline Gebied Overig & 5,4 & 0,7 & 6,1 \\
\hline Totaal & 21,4 & 9,0 & 30,4 \\
\hline
\end{tabular}

Enkele karakteristieken mestverwerkingscapaciteit

Uitgaande van de op nationale schaal gepubliceerde informatie van het BMA voor het jaar 2016 is een aantal karakteristieken wat betreft operationele en geplande installaties afgeleid. BMA heeft

177 bedrijven benaderd, waarvan er 110 hebben gereageerd. Het ging hierbij om 63\% operationele bedrijven (69), 31\% initiatieven en $6 \%$ niet meer actieve bedrijven. Op basis hiervan kan het volgende worden geconcludeerd ten aanzien van de operationele installaties:

- Mobiliteit: $96 \%$ wordt verwerkt in vaste installaties en $4 \%$ door mobiele installaties.

- Eigendom: 40\% van de operationele installaties is in eigendom van loonbedrijven/intermediairs, $30 \%$ in eigendom van alleen veehouders, $5 \%$ in eigendom van zowel veehouders als loonbedrijven en de resterende $25 \%$ van de installaties is in handen van andere partijen dan veehouders of loonbedrijven.

- Locatie: $82 \%$ van de installaties is gevestigd in het landelijke gebied en $18 \%$ op bedrijventerreinen.

- Mestsoorten: De verwerkte mest bestaat uit 33\% varkensmest, $29 \%$ rundermest, $17 \%$ pluimveemest en $21 \%$ overige mestsoorten.

- Mestbestemming: ca. 47\% wordt als geheel vanaf de mestverwerkingsinstallatie geëxporteerd, ca. $22 \%$ gedeeltelijke export vanaf installatie en ca. 31\% doorlevering naar derden.

- Gemiddelde capaciteit per bedrijf, exclusief pluimveemest (zie Tabel 4): 29,5 miljoen kg fosfaat/ $(69-1)=0,4$ miljoen $\mathrm{kg}$ fosfaat per mestverwerkingsinstallatie. 


\section{$4 \quad$ Ruimtelijke ordening en mestbewerking en -verwerking}

Het bewerken en verwerken van mest kan effect hebben op de omgeving. In de ruimtelijke ordening is vooral het vergisten van mest een aandachtspunt. Op verschillende overheidslagen is er beleid uitgewerkt dat in de volgende paragrafen kort wordt beschreven.

\subsection{Landelijk beleid}

In Bijlage I, onderdeel C van het Besluit omgevingsrecht (Bor), staat welke technieken om mest te bewerken of te verwerken leiden tot een vergunningplicht. Het Bor maakt daarbij onderscheid tussen bewerken en verwerken van dierlijke mest. Het bewerken van mest is het behandelen van dierlijke mest zonder het product noemenswaardig te veranderen. Bijvoorbeeld het mengen, roeren of homogeniseren van mest, het drogen van mest, het hygiëniseren van mest en het mechanisch scheiden van de mest in een dunne en een dikke fractie.

Voor het verwerken van dierlijke mest is altijd een omgevingsvergunning milieu nodig. Een uitzondering hierop is het kleinschalig vergisten van alleen dierlijke mest (verwerkingscapaciteit maximaal $25.000 \mathrm{~m}^{3}$ per jaar). Voor deze activiteit zijn voorschriften opgenomen in het Activiteitenbesluit en is een omgevingsvergunning beperkte milieutoets (OBM) voldoende. Een OBM is niet vereist als de activiteit deel uitmaakt van een IPPC-installatie. In dat geval moet de omgevingsvergunning milieu worden gewijzigd.

Gemeenten zijn bevoegd gezag vergunningverlening voor het kleinschalig bewerken, verwerken, opslaan of overslaan van dierlijke of overige organische meststoffen. Provincies zijn bevoegd gezag voor vergunningverlening voor de grootschalige mest verwerkende bedrijven waarbij meer dan $25.000 \mathrm{~m}^{3}$ per jaar verwerkt wordt, vanwege bovengemeentelijke milieueffecten en bovengemeentelijke verdelingsvraagstukken.

Voor het beoordelen van bewerken en verwerken van mest op boerderijschaal is een handreiking beschikbaar die zich richt op 1) mest- en digestaatscheiding, 2) hygiëniseren van mest, 3) drogen van mest en 4) kleinschalig vergisten van mest (monovergisten). In deze handleiding wordt per onderwerp aandacht besteed aan geluid, geur, luchtemissies, luchtkwaliteit, afvalwater, bodem en gezondheid.

\subsection{Provinciaal beleid}

In de provinciale omgevingsvisie Gelderland (2015) wordt gesproken over locaties voor biomassavergistingsinstallaties gekoppeld aan het thema Energie. In de nadere uitwerking daarvan in de Omgevingsverordening Gelderland (2015) blijkt het niet alleen over vergistingsinstallaties te gaan, maar er ook mestbewerking- en mestverwerkingsinstallaties onder worden verstaan. In de toelichting van de omgevingsverordening (2015) staat:

Bio-vergistingsinstallaties en mestbewerkings -en mestverwerkingsinstallaties die gebruikmaken van agrarische biomassastromen die liggen in de directe omgeving van waar deze biomassastromen beschikbaar, zijn toegestaan in het landelijk gebied. Dergelijke installaties zijn toegestaan op een bestaand agrarisch bouwblok van een agrarisch bedrijf, een agrarisch hulp- of nevenbedrijf of vrijkomende agrarische locaties in overig agrarisch gebied. Daarbij moet toetsing op infrastructurele en landschappelijke effecten hebben plaatsgevonden.

Wat de directe omgeving is, verschilt per initiatief. Het gaat erom dat initiatieven die gebruikmaken van lokale aanvoer van biomassa een centrale plek binnen de biomassastromen kunnen vinden. 
Voorkomen moet worden dat er onnodig wordt gesleept met biomassa en dat extra transport van biomassa overbelasting van het bestaande wegennet en verkeersonveilige situaties veroorzaakt.

Bij bio-vergistingsinstallaties die hieraan niet voldoen, moet in de toelichting van het bestemmingsplan worden aangetoond dat bij de locatiekeuze rekening is gehouden met de volgende voorkeursvolgorde:

a. op of grenzend aan een bedrijventerrein, glastuinbouwgebied of locaties bij soortgelijke bedrijven, zoals rioolwaterzuiveringsinstallaties of mestverwerkers die op een solitaire bedrijfslocatie zitten;

b. op bestaande agrarische bouwpercelen van een agrarisch bedrijf, bestaande bouwpercelen van een agrarisch hulp -of nevenbedrijf of vrijkomende agrarische locaties in overig agrarisch gebied.

Naarmate men bij de locatiekeuze verder naar onderen op deze lijst terechtkomt, zal nauwkeurig moeten worden aangetoond dat er een duidelijke relatie is met de agrarische functies in het gebied.

De volgende uitgangspunten liggen ten grondslag aan bovenstaande voorkeursvolgorde. Het moet zo (goed mogelijk) passen in het landschap, dus bij voorkeur gekoppeld worden aan daartoe geëigende of vergelijkbare landschappelijke elementen (om verrommeling tegen te gaan). Een landschappelijk inpassingsplan kan dit aantonen. Nuttige toepassing van warmte en/of andere (neven)producten zijn sterk bepalend bij het vinden van de juiste locatie. Wanneer de warmte niet bijna-volledig binnen het bedrijf benut wordt, ligt koppeling / leveringsmogelijkheid aan bedrijven(terreinen) en/of woonlocaties voor de hand. Verkeersbewegingen moeten beperkt worden uit oogpunt van (energie)efficiëntie, milieuaspecten en congestieproblematiek. De inrichting moet verkeerstechnisch goed ontsloten zijn.

\subsection{Gemeentelijk beleid Ede}

In het bestemmingsplan buitengebied van de gemeente Ede (2012) wordt met name ingegaan op biomassa-vergistingsinstallatie. Over mestbewerking- of mestverwerkingsinstallatie wordt niet gesproken. Uit ambtelijke gesprekken blijkt dat, evenals in het provinciale beleid, voor deze installaties dezelfde locatiekeuzes gelden als voor vergistingsinstallaties.

In de structuurvisie is de notitie 'een ruimtelijke kijk op mestvergistingsinstallaties' verwerkt. Hierin is aangegeven dat grootschaligere mestvergisting niet wordt uitgesloten in Ede. Gelet op het provinciale beleid heeft de gemeente beleidsruimte gekregen ten aanzien van mestvergistingsinstallaties met een verwerkingscapaciteit die kleiner is dan 36.000 ton mest. Voor een nadere invulling hoe deze ruimte is ingevuld, wordt verwezen naar de Structuurvisie Buitengebied. Op basis van de beleidsuitspraken van de structuurvisie kunnen er aparte planologische procedures worden opgestart (een zogenaamd 'postzegelplan').

De effecten op de omgeving van iedere mestvergistingsinstallatie worden echter bepaald door de aard en omvang van het initiatief en de beoogde locatie. Daarom is het onmogelijk gebleken om een wijzigingsbevoegdheid te schrijven waarbij op voorhand vaststaat dat deze werkzaam is voor de op handen zijnde initiatieven.

Het gemeentelijke beleid laat zich samenvatten als:

Grootschalige mestvergisting is niet toegestaan in voorliggend bestemmingsplan, maar vraagt om een specifieke afwijking op basis van een afzonderlijk plan. Mestvergisting op boerderijniveau van de bedrijfseigen mest is toegestaan. 


\section{$5 \quad$ Ontwikkelingen mestverwerking}

De opgave voor de Nederlandse landbouw is om in 2017 te komen tot een evenwicht op de mestmarkt, waarbij evenveel mest wordt verwerkt als het verschil tussen de mestproductie en de plaatsingsruimte in Nederland. Er zijn kansen die mestverwerking een stap verder kunnen brengen. Daarnaast zijn er ook ontwikkelingen die mogelijk een belemmering kunnen zijn voor mestverwerking. In paragraaf 5.1 gaan we in op de kansen en bedreigingen. In paragraaf 5.2 worden de belangrijkste uitkomsten uit de regionale expertmeeting weergegeven.

\subsection{Kansen en bedreigingen}

\subsubsection{Ontwikkelingen mestbewerking en -verwerking}

Het doel van mest verwerken kan zijn productie van waardevolle componenten voor hergebruik, productie van energie, voorkomen van emissies of betere benutting van mest. Dit kunnen verschillende technieken of combinaties daarvan. Hieronder schetsen we een aantal ontwikkelingen.

\section{Schaalniveau mestverwerking}

De vraag bij deze ontwikkeling is vaak of het op boerderijschaal mogelijk is of dat grootschalige mestverwerking nodig is. In de praktijk zijn de nettokosten (brutokosten minus de opbrengsten) de bepalende factor voor het verwerkingsproces (Rulkens, 2015). In deze studie gaan we niet verder in op deze kosten. Wel constateren we dat de brutokosten toenemen naarmate het complexere verwerkingsprocessen worden en het daarmee eerder interessant is om op grootschalige manier te gaan toepassen dan op kleinschalige boerderijschaal.

\section{Mestvergisting}

Zoals in paragraaf 2.2 staat aangegeven, valt vergisten van mest niet onder de definitie mestverwerking. Vergisting is een zuurstofloos biologisch proces waar micro-organismen organisch materiaal ten dele afbreken. Hierbij worden biogas en digestaat gevormd. Het digestaat wordt gewoon als dierlijke mest beschouwd en kan, evenals ruwe mest, worden aangewend of verder worden verwerkt tot een vaste en een vloeibare fractie die min of meer dezelfde eigenschappen hebben als bij ruwe mest.

Mestvergisting gebeurt op twee manieren; covergisten of monovergisten. Er zijn in Nederland ongeveer 100 locaties waar mest samen met hoogcalorische substraten vergist worden. De groei van de productie van hernieuwbare energie uit covergisting van mest vlakt af vanaf 2009 . Ongeveer $3 \%$ van de mestproductie in Nederland ging in 2015 de vergisters in (CBS, 2016). Maïs is een belangrijk co-product dat wordt meevergist. Vanwege de hoge prijzen wordt er steeds minder maïs meevergist. Naast maïs wordt een hele range aan verschillende producten meevergist. Het kan gaan om resten uit de voedingsmiddelenindustrie, de handel in levensmiddelen, diervoederindustrie of de primaire landbouw. Huidige mestvergisters draaien niet op de volledige capaciteit vanwege de hoge prijzen voor hoogcalorische cosubstraten (CBS, 2016). Covergisting met mest heeft als nadeel dat het mestoverschot vergroot wordt. Het restmateriaal afkomstig uit covergisters (zowel mest als ook het cosubstraat) wordt volledig beschouwd als dierlijke mest.

Bij monovergisten wordt enkel mest vergist, zonder cosubstraat. Het komt in Nederland nog weinig voor; de installaties zijn door de hoge kosten en het lage rendement moeilijk rendabel te houden. Recentelijk is coöperatie Jumpstart opgestart. Daarin zijn FrieslandCampina, Groen Gas Nederland, Duurzame Zuivelketen (DZK), LTO en NZO vertegenwoordigd. Ze streven naar het realiseren van monovergisters op boerderijschaal bij 200 melkveehouders met uiteindelijk in 2020 zo'n 1000 installaties. Jumpstart faciliteert melkveehouders bij het verkrijgen van financiering, aanvraag vergunningen en subsidies. Daarvoor maakt Jumpstart collectieve afspraken met leveranciers en 
afnemers. Daarnaast worden de vergisters flink gefinancierd door overheidssubsidie (SDE+). De belangstelling onder melkveehouders is redelijk groot (bijna 500 bedrijven, nov. 2016), maar er heerst ook scepsis of het uiteindelijk rendabel wordt (FD, 28 augustus 2016).

\section{Mestscheiding}

De belangstelling voor scheiding van runder- en varkensmest op bedrijfsniveau neemt toe. De dikke fractie (fosfaatrijk) wordt dan gescheiden van de dunne fractie (stikstofrijk). De dikke fractie wordt dan afgevoerd voor verdere verwerking, terwijl de dunne fractie op eigen bedrijf of directe omgeving kan worden afgezet op de landbouwgronden. Dit scheelt transportkosten voor afvoer van fosfaten en hogere afzet van stikstof op eigen bedrijf of omgeving. Vooral voor veehouders met eigen grond of voor bedrijven met afzetmogelijkheden in de nabije omgeving is mestscheiding interessant.

\section{Mineralenconcentraat}

Het mineralenconcentraat is een product met een hoog stikstof $(N)$ gehalte en een laag fosfor $(P)$ gehalte. Het mineralenconcentraat, dat ontstaat uit een bewerking van de dunne fractie (omgekeerde osmose), kan gebruikt worden als kunstmestvervanger. In principe mag iedereen mineralenconcentraat gebruiken, mits het als meststof binnen de stikstofgebruiksnorm dierlijke mest wordt toegepast. Het mineralenconcentraat is echter nog niet als vervanger van kunstmest toepasbaar, omdat het aangemerkt wordt als dierlijke mest. Wel kan door de inzet van mineralenconcentraat met de agronomisch gewenste samenstelling ( $N: P: K$-verhouding) de afzetmogelijkheden worden vergroot.

Proeven met mineralenconcentraat (Velthof, 2011, 2015) wijzen uit dat de beschikbaarheid van stikstof in het concentraat gemiddeld $80 \%$ is, ten opzichte van een $100 \%$ beschikbaarheid in kunstmest. Uit landbouwkundig oogpunt presteert het concentraat dus minder goed voor een akkerbouwer dan kunstmest. Diverse proeven bieden echter wel perspectief dat de stikstofwerking naar ca. 90\% kan. Verder zijn er ook voordelen van het concentraat ten opzichte van kunstmest. Mineralenconcentraat is goedkoper dan kunstmest en bevat bovendien naast stikstof ook kalium, een belangrijke meststof voor bijvoorbeeld de aardappelteelt. Duidelijk is ook dat het mineralenconcentraat niet leidt tot meer nitraatuitspoeling naar grond- en oppervlaktewater, en dus geen effect heeft op het realiseren van de doelstellingen uit de Nitraatrichtlijn. Financieel kan het interessant zijn om mineralenconcentraat toe te gaan passen.

Scenarioberekeningen (Lesschen et al. 2011) laten zien dat grootschalige toepassing van mineralenconcentraten onder de veronderstelde condities voor 2015 (gebruiksnormen 2015, excreties 2009 en huidige derogatie) leidt tot een hogere mestplaatsingsruimte voor mest (waardoor er minder mestexport nodig is). Hierdoor neemt het gebruik van zowel (conventionele) stikstof- als fosfaatkunstmest in Nederland af. Verder leidt het grootschalig toepassen van mineralenconcentraten niet tot extra ruimte binnen de gebruiksnormen voor een hogere mestproductie (en grotere omvang veestapel).

Momenteel hebben tien producenten een vrijstelling om erkend mineralenconcentraat als kunstmest te maken. Om het concentraat daarvoor door iedereen te kunnen gebruiken, moeten Europese richtlijnen (mestverordening en Nitraatrichtlijn) worden aangepast. Daar wordt al jaren over gesproken/gelobbyd in Brussel. De lange politieke onduidelijkheid over de status van mineralenconcentraat in combinatie met praktische beperkingen, maakt dat producenten andere oplossingen zoeken. De afzet van de producten is immers medebepalend voor het rendement van mestverwerking.

\section{Mestraffinage}

Bij mestraffinage worden de fracties uit mestverwerking verder opgewerkt tot aparte fosfaat-, stikstofen kaliproducten. De producten vragen minder opslag vragen en kunnen beter aansluiten bij de vraag vanuit binnen- en buitenland. Mestraffinage bevindt zich vooral nog in de ontwikkel- en demonstratiefase.

De Gelderse bedrijven Groot Zevert Vergisting, Nijhuis Water Technology en Wageningen Research werken sinds 2014 nauw samen aan de ontwikkeling van de 'Groene Mineralen Centrale'. In deze centrale wordt mest verwerkt tot verschillende producten: nutriënten (fosfaat, stikstof en kalium), 
biogas, mineraalarme organische stof en proceswater. Recentelijk hebben deze bedrijven vanuit het Europese programma Horizon2020 en de Topsector Agri\&Food steun gekregen voor een grootschalig demonstratieproject. Deze eerste grootschalige toepassing van de 'Groene Mineralen Centrale' voor de verwerking van varkensmest wordt binnenkort bij Groot Zevert Vergisting gerealiseerd. De installatie gaat jaarlijks 100.000 ton varkensmest verwerken tot onder meer minerale meststoffen.

Mest als onderdeel van een kringloopsysteem

Ecoferm (Uddel) en Kringloopboeren (Noord-Nederland) zijn voorbeelden van landbouwsystemen waarin getracht wordt de emissies naar het milieu te reduceren door interne kringlopen te creëren.

Ecoferm is een grootschalige kalverhouderij met een innovatieve stal waarin verschillende kringlopen tot stand gebracht worden. Naast kalveren produceert het ook energie (biogas) en eendenkroos. Het kroos wordt gebruikt als veevoer en om het water te zuiveren. In plaats van het afzetten van drijfmest worden meer hoogwaardige mestproducten (gedroogde biomassa met $P$ en ingedikt mineralenconcentraat) geproduceerd, waarmee hoge kosten van drijfmestafzet worden vermeden.

In Noord-Nederland zijn boeren actief die gezamenlijk werken aan kringlooplandbouw. Deze kringloopboeren gebruiken zo veel mogelijk grondstoffen van het eigen bedrijf of anders uit de regio. Bijzondere aandacht is er voor het reduceren van internationale afhankelijkheid, met name van de invoer van veevoer. Hiermee worden fossiele brandstoffen bespaard en dus $\mathrm{CO}_{2}$-emissies. Ook wordt er minder stikstof $(N)$ en fosfor $(P)$ geïmporteerd. Daarnaast is in de kringlooplandbouw veel aandacht voor een vitale bodem. Door een actief bodemleven (dus met veel bodembiodiversiteit) en de opbouw van organische stof, vindt mineralisatie van stikstof en mobilisatie van fosfor plaats; dit kan een verminderde kunstmestgift compenseren.

\subsubsection{Bedreigingen}

Afzet van dierlijke mest in buitenland wordt komende jaren lastiger

Dierlijke mest verwerkt tot mestkorrels gaat al jarenlang naar tientallen landen over de hele wereld. Onbehandelde mest die geëxporteerd wordt, gaat echter niet de hele wereld over. Deze wordt met name afgezet in de buurlanden Duitsland en België. Hoewel er de laatste jaren een toename is van export naar deze landen, wordt het voor de Nederlandse mestmarkt belangrijk geacht om nieuwe afzetmarkten aan te boren. De buitenlandse overheden zien de komst van Nederlandse mest niet altijd zitten. In Duitsland en Frankrijk worden de regels omtrent het gebruik van (dierlijke) mest steeds verder aangescherpt. Daarbij kampen diverse Duitse deelstaten zelf met een mestoverschot. Duitse boeren moeten zelf ook meer mest afvoeren. Het veelgebruikte digestaat uit vergisters is tegenwoordig ook gemerkt als mest. Dit verkleint de gebruiksruimte van de Duitse akkerbouwer voor overige dierlijke mestproducten aanzienlijk.

\section{Geplande mestverwerkingscapaciteit komt niet van de grond}

Het realiseren van mestverwerkingsinstallaties gaat om allerlei redenen niet altijd eenvoudig. Een aantal redenen hiervoor:

1. Maatschappelijke weerstand tegen grootschalige installaties waardoor vergunningverlening wordt opgehouden of zelfs niet doorgaat.

Direct-omwonenden maken zich steeds meer zorgen over overlast (geur, toename verkeersbewegingen), gezondheidsrisico's en calamiteiten. Daarnaast wordt het argument 'aanzuigende werking' m.b.t. de ontwikkeling veehouderij genoemd. In de provincie NoordBrabant zijn in 2016 diverse stakeholders bijeengebracht in een mestdialoog om de problematiek te bespreken. Uitkomst is dat naast verdere inzet op mestverwerking daarbij ook aandacht wordt besteed aan locatiekeuze (grootschalig, zo veel mogelijk op bedrijventerreinen), een houdbaar en helder toetsingskader bij vergunningverlening met daarin specifiek aandacht voor volksgezondheid en een aanpak om daar waar nodig groei van veehouderij tegen te gaan (Prov. Noord-Brabant, 2016).

2. Financiering en contracteren van voldoende mest.

Het realiseren van een grootschalige mestverwerkingsinstallatie vraagt om een grote investering. Daar komt bij dat voor financiering ook duidelijk dient te zijn dat er voldoende mest aangeboden gaat worden. Daarvoor worden contracten met agrarische ondernemers afgesloten. Beide 
aspecten vergen veel inspanning. Ondernemers zijn enigszins terughoudend om zich voor langere termijn te verbinden aan een initiatief dat zijn bestaansrecht nog moet bewijzen.

Dit aspect speelt bijvoorbeeld bij de initiatiefnemers het mestverwerkingsproject Greenferm in Apeldoorn. Daar willen ze op jaarbasis 350.000 ton drijfmest verwerken. De vergunningen zijn verleend. Nu dient er nog voor 100.000 ton drijfmest gecontracteerd te worden voordat financiering rond is en er gestart kan worden (AgriHolland, 2017).

3. Technische problemen

Mestverwerking is een relatief jonge bedrijfstak en de technologie is nog volop in ontwikkeling. Een deel van de installaties kampt met technische problemen waardoor er installaties gedeeltelijk of geheel stil komen te liggen. Naast oplossen van de technische problemen is dan vaak ook extra financiering nodig.

\section{Derogatie vervalt}

In paragraaf 2.1 werd al aangegeven dat de kans bestaat dat de derogatie komt te vervallen als Nederland niet onder het fosfaatplafond blijft. De gevolgen voor de veehouderij en mestmarkt zijn dan substantieel. De veestapel zal dan moeten krimpen en de orde van grootte is dan afhankelijk van de beschikbare mestverwerkingscapaciteit. Het aantal melkkoeien zal met 2 tot $5 \%$ moeten dalen. Echter, door de toegenomen kosten voor mestafzet is het waarschijnlijk in elke veehouderijsector rendabeler om het aantal dieren te verminderen. De grootste daling treedt op in de varkenshouderij; deze sector kan - evenals de sector 'overig rundvee' - moeilijker concurreren op de mestmarkt met de melkveehouderij (De Koeijer, 2016).

\section{Vergeet stikstof niet!}

Dat was de uitspraak van prof. O. Oenema in de Boerderij van 1 februari 2016 en de titel van een artikel in Boerderij 11 maart 2016. Daarin wordt aangegeven dat als het fosfaatoverschot eenmaal onder controle is, stikstof eraan komt. Iets wat ook tijdens de expertmeeting onder de aandacht gebracht werd. Stikstofoverschotten die water, bodem én lucht belasten, vormen wereldwijd een groot milieuprobleem. Stikstof spoelt uit, het vervluchtigt, het gaat makkelijk van de ene vorm over in de andere. Na mestscheiding zit het in de dunne fractie. Indien er op den duur meer afgezet moet worden, betekent dat grotere volumes afvoer en hoge transportkosten.

\subsection{Resultaten expertmeeting}

Op 6 januari 2017 bespraken we met een aantal deskundigen van gemeenten, provincie, Omgevingsdienst, agrarische sector en mestmarkt (zie Bijlage 2 voor lijst met deelnemers) de opgave voor mestverwerking in de gemeente Ede en omringende gemeenten.

Belangrijke noties uit deze expertmeeting:

- De opgave voor mestverwerking is duidelijk en voor de gemeente Ede en omringende gemeenten groot. De omvang te verwerken pluimveemest is groot, maar hier zijn al structurele kanalen voor opgezet, zoals bij BMC Moerdijk. Veel kalvergier wordt verwerkt door Stichting Mestverwerking Gelderland (SMG). Wel is hier behoefte aan meer verwerkingscapaciteit, omdat de samenstelling van de kalvermest in de loop der jaren is veranderd doordat er meer rosé vleeskalveren ten faveure van de blanke vleeskalveren zijn gekomen. De mest van de rosé vleeskalveren lijkt meer op de mest uit de melkveehouderij en bevat meer droge stof dan de mest van blanke vleeskalveren. De grootste opgave ligt bij verwerking van varkensmest; deze is lastiger te plaatsen bij boeren elders dan rundveemest. Varkensmest is echter goed te verwerken, alleen is er onvoldoende verwerkingscapaciteit voor in de regio.

- Naast fosfaat verwacht men de komende jaren dat er ook voor de stikstof in de dunne mestfractie meer verwerkingscapaciteit nodig zal zijn.

- Ondanks de noodzaak voor extra mestverwerkingscapaciteit bestaan er twijfels of alle geplande initiatieven wel doorgang zullen vinden. Vaak is voorinschrijving en inleg van veehouders nodig waarbij ze zich voor een langere tijd dienen te committeren aan de verwerker. Niet iedere veehouder wil zich, gezien slechte ervaringen uit het verleden, op deze manier vastleggen en zoekt naar besparingen op korte termijn in plaats van zekerheid (tegen een iets hogere prijs) op lange 
termijn. Te weinig commitment betekent vaak dat de financiering van het project onder druk komt te staan en het project vertraagt of niet rond komt.

- Een alom gedeelde mening onder de aanwezigen was dat het belangrijk is dat de veehouders de initiatieven voor mestverwerking moeten dragen. Veel initiatieven worden genomen door de verwerkingssector, maar zolang er geen tot beperkte interesse is bij boeren om de mest daar ook daadwerkelijk te laten verwerken, is het de vraag of er voldoende draagvlak bij verschillende partijen zal zijn om het initiatief daadwerkelijk te kunnen starten.

- Verder werd aangegeven dat nieuwe ontwikkelingen en innovaties experimenteerruimte nodig hebben binnen wet- en regelgeving. Als voorbeelden werden het lozen van zuiver water op oppervlaktewater of mineralenconcentraat als kunstmestvervanger genoemd. Belangrijk is dat overheden deze regelruimte voor innovaties met een positieve grondhouding kunnen faciliteren.

- Algemeen advies aan de gemeente Ede is dat mestverwerkingsinitiatieven zeker wenselijk zijn in de regio, maar wel onder de voorwaarden dat er voldoende draagvlak is bij de lokale veehouders om de mest daar ook te verwerken. 


\section{Conclusies en aanbevelingen}

\subsection{Conclusies}

\section{Mestproductie en -transport}

- De productie van mest en de mineralen stikstof en fosfaat in Ede en omringende gemeenten is een van de hoogste in ons land. De mestproductie in de gemeente Ede bedroeg in 2014 3,4 mln kg fosfaat, hoofdzakelijk in pluimvee-, varkens- en kalverenmest. Het fosfaatoverschot in Ede bedroeg in 2014 3,2 mln kg fosfaat. Dat wil zeggen dat in de gemeente Ede 95\% van de productie fosfaat in mest niet op eigen grond kan worden toegediend.

- Het merendeel van het mestoverschot van de veehouderijen in Ede wordt buiten de gemeente afgezet. Het gaat naar bedrijven die nog plaatsingsruimte voor mest hebben of de mest verwerken. Veel mest (54\%), met name varkens- en pluimveemest, wordt afgezet in regio's buiten de gebieden met veel veehouderij. Het gaat dan om de rest van Nederland, buiten de regio's Oost en Zuid. Verder wordt 14\% van het overschot, met name pluimveemest, rechtstreeks naar het buitenland getransporteerd.

\section{Mestverwerkingsplicht}

- De plicht om een deel van het overschot te verwerken, is sinds de invoering in 2014 jaarlijks aangescherpt. In 2014 was de verwerkingsplicht 15\% van het bedrijfsoverschot, terwijl dit percentage voor 2017 is opgeschroefd naar 52\% van het bedrijfsoverschot. Voor de gemeente Ede werd in 2014 ruimschoots voldaan aan de verwerkingsplicht. Er werd 39\% meer verwerkt dan de verplichte hoeveelheid. Dit werd echter voornamelijk gerealiseerd door de verwerking van pluimveemest.

- Uitgaande van de verwerkingsplicht voor het jaar 2017 en gebaseerd op de productie en verwerking in 2014, dient er ten opzichte van 2014 nog ca. 0,7 mln kg fosfaat meer verwerkt te worden.

\section{Mestverwerkingscapaciteit}

- Waar de mest verwerkt wordt, is niet regionaal gebonden. Dus de te verwerken mest in de gemeente Ede mag overal in Nederland verwerkt worden. Er is alleen per mestregio (Oost, Zuid, Overig) informatie beschikbaar over de omvang van de mestverwerkingscapaciteit. In regio Oost is de mestverwerkingscapaciteit gering en bedraagt in $20161,3 \mathrm{mln} \mathrm{kg}$ fosfaat. Totaal in Nederland bedraagt de mestverwerkingscapaciteit in 2016 zich tussen 29,5 tot $36 \mathrm{~kg} \mathrm{mln}$ fosfaat.

- De mestverwerkingscapaciteit in Nederland is in 2016 onvoldoende geweest om aan, de voor 2017 vastgestelde, verwerkingsplicht te voldoen (37,1 miljoen $\mathrm{kg}$ fosfaat). Er zijn echter veel projecten in ontwikkeling waarmee de verwachting is dat de verwerkingscapaciteit binnen enkele jaren voldoende is voor de mestverwerkingsplicht.

- In regio Oost zijn veel projecten in ontwikkeling en hoewel de verwerkingsplicht niet regionaal gebonden is, komt daarmee de verwerkingscapaciteit in Oost steeds dichter bij het volume van de verwerkingsplicht in Oost.

- Met name voor varkens- en kalvermest is de opgave voor extra verwerkingscapaciteit in de regio het grootst. Voor varkensmest ontbreekt voldoende verwerkingscapaciteit in de regio en voor kalvermest is meer verwerkingscapaciteit nodig vanwege de veranderende samenstelling van de mest. De omvang te verwerken pluimveemest is groot, maar hier zijn al structurele kanalen voor opgezet, zoals bij BMC Moerdijk.

\section{Kansen en bedreigingen mestverwerking}

- Een van de grote bedreigingen voor de mestverwerking is dat de geplande initiatieven niet van de grond komen. Daarvoor zijn verschillende oorzaken aan te wijzen, zoals de trage vergunningverlening en maatschappelijke weerstand, gebrek aan financiering en voorinschrijving veehouders en technische problemen.

- Als de capaciteit voor mestverwerking onvoldoende is, wordt export van mest steeds belangrijker. Echter, de afzet van dierlijke mest in buitenland wordt de komende jaren steeds lastiger. De regio's 
langs onze grenzen kampen zelfs steeds meer met mestoverschotten. Verder weg gelegen afzetgebieden zullen nodig zijn.

- Dierlijke mest bevat waardevolle meststoffen. De komende jaren zal de techniek dat de meststoffen uit de dierlijke mest gescheiden worden en in potentie als kunstmestvervanger ingezet kunnen worden, zich steeds verder ontwikkelen. Dit zal kosten voor de veehouder besparen (verwaarden van mest en minder kunstmestgebruik). Wel dienen deze mineralen uit dierlijke mest dan door Brussel te moeten worden geaccepteerd als kunstmestvervanger.

\section{Mestverwerking en ruimtelijke ordening}

- Gemeenten zijn bevoegd gezag vergunningverlening voor het kleinschalig bewerken, verwerken, opslaan of overslaan van dierlijke of overige organische meststoffen. Provincies zijn bevoegd gezag voor vergunningverlening voor de grootschalige mest verwerkende bedrijven waarbij meer dan $25.000 \mathrm{~m}^{3}$ per jaar verwerkt worden, vanwege bovengemeentelijke milieueffecten en bovengemeentelijke verdelingsvraagstukken. Het beleid van de provincie Gelderland is erop gericht dat in het landelijk gebied mestverwerking mogelijk is als er gebruikgemaakt wordt van agrarische biomassastromen gelegen in de directe omgeving.

- Indien deze directe relatie niet of beperkt aanwezig is, gaat de voorkeur uit naar locaties op of grenzend aan een bedrijventerrein, glastuinbouwgebied of locaties bij soortgelijke bedrijven, zoals rioolwaterzuiveringsinstallaties of mestverwerkers die op een solitaire bedrijfslocatie zitten. Het beleid van de gemeente Ede geeft aan dat mestverwerking op boerderijniveau met bedrijfseigen mest is toegestaan. Grootschalige mestverwerking is niet zonder meer toegestaan in het bestemmingsplan, maar vraagt om een specifieke afwijking op basis van een afzonderlijk plan.

- De ontwikkelingen in mestverwerking laten zien dat mestverwerking zowel kleinschalig als grootschalig kan plaatsvinden. Indien bedrijven groot genoeg zijn (> $10.0000 \mathrm{~m}^{3}$ mest), kan het aantrekkelijk zijn om dit op boerderijschaal te doen. Het is echter de verwachting dat met name op boerderijschaal wordt ingezet op het bewerken van mest met behulp van eenvoudige technieken, zoals het scheiden van dikke en dunne fractie en dat verdere verwerking meer op centrale, grootschalige manier zal plaatsvinden. Dit omdat dit complexere processen zijn die een bepaalde schaalgrootte vergen om tot een aantrekkelijke tarief voor verwerking te komen.

\subsection{Aanbevelingen}

Veel mest uit Ede wordt elders verwerkt. Vooral voor varkens- en kalvermest is er een noodzaak voor meer verwerkingscapaciteit. Aangezien transport een deel van de verwerkingskosten bepaalt, kan het aantrekkelijk zijn om de mest op eigen bedrijf te scheiden en vervolgens in de eigen regio te laten verwerken. Daarvoor is meer centrale grootschalige verwerkingscapaciteit nodig. Er zijn voldoende initiatieven die daarin kunnen voorzien, de vraag is echter of deze allemaal haalbaar zijn.

We doen daarom de volgende aanbevelingen voor de gemeente Ede en omringende gemeenten:

- Ondersteun mestverwerkingsinitiatieven met een haalbare businesscase en met regionaal draagvlak. Concreet betekent dit dat er voor deze initiatieven voldoende deelname van boeren uit de regio is en dat de initiatiefnemers in dialoog met de omgeving de plannen en ruimtelijke inpassing zodanig vormgegeven hebben dat de overlast voor de omgeving beperkt blijft.

- Bepaal als gemeente aan welke voorwaarden locaties moeten voldoen voor grootschalige mestverwerking. Maatwerk per initiatief is nodig, maar een nadere invulling van het huidige gemeentelijke beleid biedt duidelijkheid voor initiatiefnemers. Aangezien mestverwerking niet gebonden is aan de gemeentegrenzen, is afstemming in regionaal verband wenselijk.

- Creëer ruimte voor innovatie. Technieken en bedrijfsconcepten zijn sterk in ontwikkeling; verken met regionale bedrijven en agrarisch ondernemers op welke manier ze hieraan bij kunnen dragen en wat daar voor nodig is. Denk aan het faciliteren van ondernemers, ruimte bieden in regelgeving, fysieke ruimte bieden in ruimtelijke ordening en het creëren van lerende netwerken met verschillende stakeholders. 


\section{Literatuur}

BMA, 2015. Landelijke inventarisatie mestverwerkingscapaciteit September 2014.

BMA, 2016. Landelijke inventarisatie mestverwerkingscapaciteit September 2016.

CBS, 2016. Hernieuwbare energie in Nederland 2015.

EC, 2009. Regulation (EC) No 1069/2009 of 21 October 2009 to laying down health rules concerning animal by-products not intended for human consumption and repealing Regulation (EC) No 1774/2002. Document L 300/1, European Commision, Brussel.

EZ, 2014. Meststoffenwet. (http://wetten.overheid.nl/BWBR0004054/geldigheidsdatum_02-12-2014), Ministerie van Economische Zaken, Den Haag.

EZ, 2016a. Meststoffenwet. http://wetten.overheid.nl/BWBR0004054/2016-03-01\# HoofdstukI, Ministerie van Economische Zaken, Den Haag.

EZ, 2016b. Uitvoeringsregeling Meststoffenwet. Ministerie van Economische Zaken, Den Haag.

Koeijer, T.J. de, H.H. Luesink en P.W. Blokland, 2016. Effecten van derogatie op de kosten van mestafzet. Wageningen, LEI Wageningen UR (University \& Research centre), LEI Report 2016-024.

Lesschen, J.P., I. Staritsky en G.L. Velthof, 2011. Verkenning grootschalige toepassing van mineralenconcentraten in Nederland; Effecten op nutriëntenstromen en emissies. Wageningen, Alterra, Alterra-rapport 2247.

Oenema, O., 2016. Advies 'Mestverwerkingspercentages 2017'. Wettelijke Onderzoekstaken Natuur \& Milieu, Wageningen.

Rulkens, W. 2015. Opties voor mestverwerking. Wageningen UR. http://www.pbl.nl/sites/default/files/cms/publicaties/rulkens_-_mestverwerking.pdf

Van Dam, M., 2016. Percentages verplichte mestverwerking 2017. In 00000001003214369000(Ed, M.v.E. Zaken) Ministry of Economic Affairs, The Hague, pp. 2.

Velthof, G.L., 2011. Synthese van het onderzoek in het kader van de Pilot Mineralenconcentraten Wageningen : Alterra Wageningen UR, (Alterra-rapport 2211) - 74 p.

Velthof, G.L., 2015. Mineral concentrate from processed manure as fertiliser. Wageningen : Alterra Wageningen UR, (Alterra-rapport 2650)

College B\&W gemeente Ede, zaaknummer 11790, 2014.

https://gemeenteraad.ede.nl/fileadmin/RIS/bijlagen/13120-d0464cf4-282b-467b-89fc-

f698b6de27c5.pdf 


\section{Bijlage 1 Berekeningsprocedure mestoverschot}

Voor de berekening van mestproductie en mestoverschotten is gebruikgemaakt van het model INITIATOR in combinatie met de GIABplus en BRP data voor het jaar 2014.

De berekening gaat als volgt:

- Bepaling P gebruiksnorm voor het jaar 2014:

Bepaal met INITIATOR aan de hand van bemestingshistorie de P-status (PAl voor grasland en Pw voor bouwland per Stone-plot (de ruimtelijke rekeneenheid in INITIATOR, bestaande uit 1 of meer $250 \mathrm{~m} \times 250 \mathrm{~m}$ cellen). Hierbij wordt uitgegaan van het landgebruik op basis van STONE en het areaal op basis van het CBS. Op basis van een overlay van de berekende PAl en Pw per STONE-plots en gemeente wordt per gemeente een gemiddelde P-gebruiksnorm bepaald. Hierbij laten we de $\mathrm{N}$ limitatie buitenbeschouwing, omdat de verwerkingsplicht gerelateerd aan het P-gerelateerde overschot.

- Bepaling overschot per bedrijf op basis van GIABplus 2014 en BRP 2014:

Per gemeente wordt voor de relatienummers waarvan de hoofdvesting in de gemeente ligt:

- de totale mestproductie bepaald (van zowel hoofd als nevenvestigingen, met dieraantallen uit GIABplus 2014 en WUM-excreties)

- het P gebruiksruimte op basis van het totale bedrijfsareaal (BRP 2014) en de gemeente een gemiddelde P-gebruiksnorm (afhankelijk van de gemeente waarin het perceel ligt; bij grensoverschrijdende percelen wordt get gewogen gemiddelde genomen)

- het bedrijfsoverschot: a-b (wat uitgesplitst wordt naar de diercategorieën rundvee (excl. Kalveren), kalveren, varkens, pluimvee, overig)

- Bepaling de gemiddelde fractie bedrijfsoverschot per gemeente:

- fractie bedrijfsoverschot (gemeente) (d) = som van alle bedrijfsoverschotten in gemeente (som c) / som van de totale mestproductie in gemeente (som a)

- Bepaling van overschot in een gemeente (in Mton fosfaat):

Per vestiging in een gemeente (op basis van GIABplus 2014 en WUM) wordt als volgt het overschot bepaald:

- overschot per vestiging (e) = fractie bedrijfsoverschot (gemeente) $(d) \times$ excretie per vestiging. Dit wordt eveneens uitgesplitst naar de vijf diercategorieën.

- overschot per gemeente $(f)=$ som van alle overschotten per vestiging (e) in een gemeente. Dit wordt eveneens uitgesplitst naar de vijf diercategorieën.

- Naast het totale overschot per gemeente bepalen we ook het overschot uitgedrukt in kg fosfaat per hectare door het overschot per gemeente te delen door het BRP areaal in de die gemeente.

- overschot per ha (f) = overschot per gemeente (f) / BRP areaal gemeente. 


\section{Bijlage 2 Lijst met deelnemers expertmeeting}

$\begin{array}{ll}\text { Geert Butz } & \text { Gemeente Ede } \\ \text { Edo Gies } & \text { Wageningen Environmental Research } \\ \text { Henny de Haan } & \text { Nederlandse Vakbond Pluimveehouders } \\ \text { Karin van Houwelingen } & \text { Gemeente Barneveld } \\ \text { Kees Kroes } & \text { LTO Noord } \\ \text { Hans Kros } & \text { Wageningen Environmental Research } \\ \text { Bart van Moorsel } & \text { Provincie Gelderland } \\ \text { Wesley Scheffer } & \text { Gemeente Ede } \\ \text { Jeroen Sluismans } & \text { Stichting Kiemt, provincie Gelderland } \\ \text { Peter Smaal } & \text { Gemeente Ede } \\ \text { Erik van Tol } & \text { Gemeente Ede } \\ \text { Gert Vaarkamp } & \text { Varkenshouder } \\ \text { Gerben van Veldhuizen } & \\ \text { Willemien Vreugdenhil } & \text { Gemeente Ede }\end{array}$




\section{Bijlage 3 Mestproductie, -transport en verwerking}

Tabel 5 Mestproductie, -aanvoer, -afvoer (in het kader van de verwerkingsplicht en totaal) en berekende verwerkingsplicht voor 2014 en 2017 in de gemeente Ede voor het jaar 2014 op basis van Giab-bedrijven.

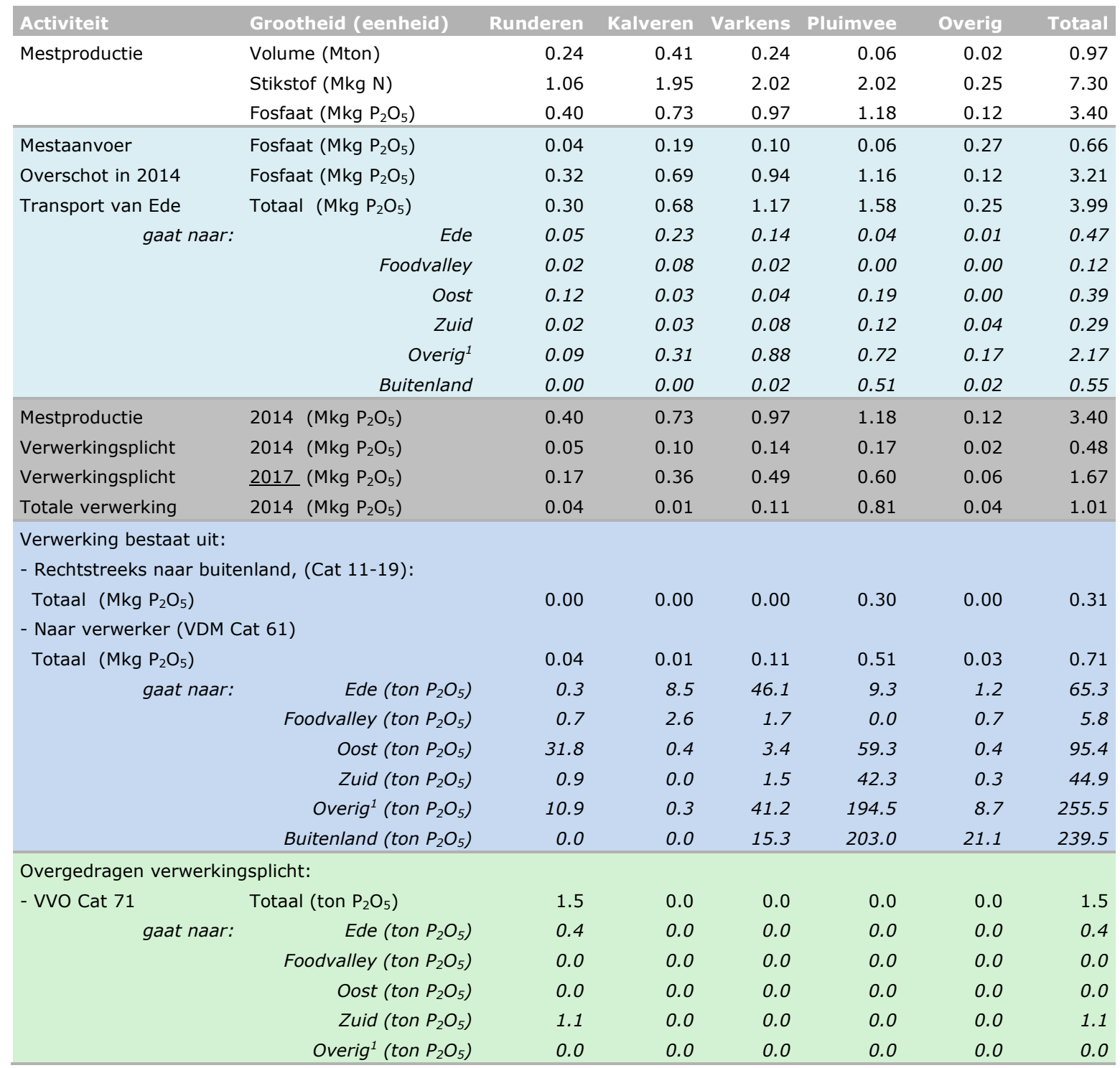

1 Rest van Nederland, particulieren en onbekend. 
Tabel 6 Mestproductie, -aanvoer, -afvoer (in het kader van de verwerkingsplicht en totaal) en berekende verwerkingsplicht voor 2014 en 2017 in de regio Food Valley ${ }^{2}$ voor het jaar 2014 op basis van Giab-bedrijven.

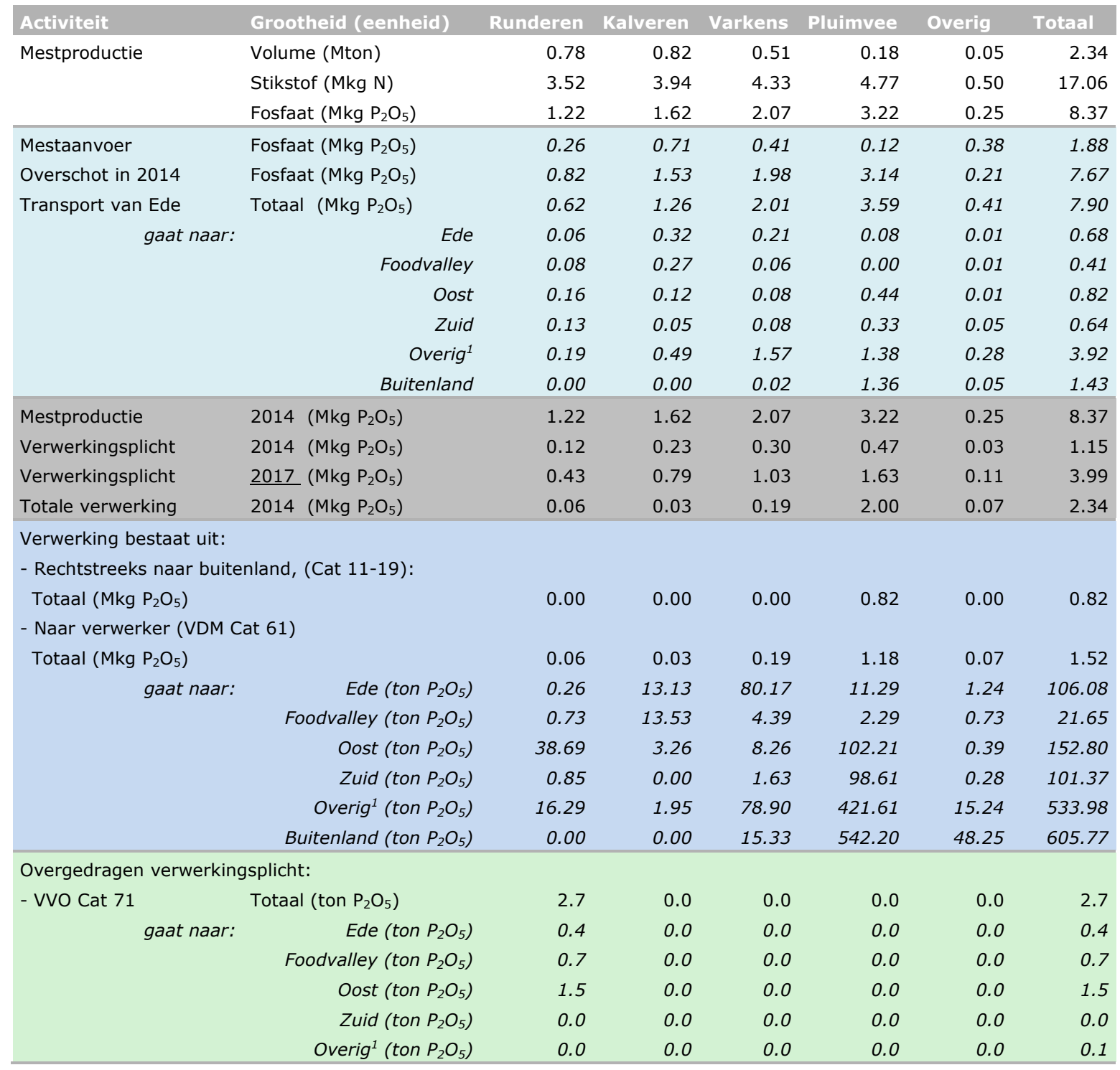

1 Rest van Nederland, particulieren en onbekend. 
Tabel 7 Mestproductie, -aanvoer, -afvoer (in het kader van de verwerkingsplicht en totaal) en berekende verwerkingsplicht voor 2014 en 2017 in de regio Oost-Nederland ${ }^{2}$ voor het jaar 2014 op basis van Giab-bedrijven.

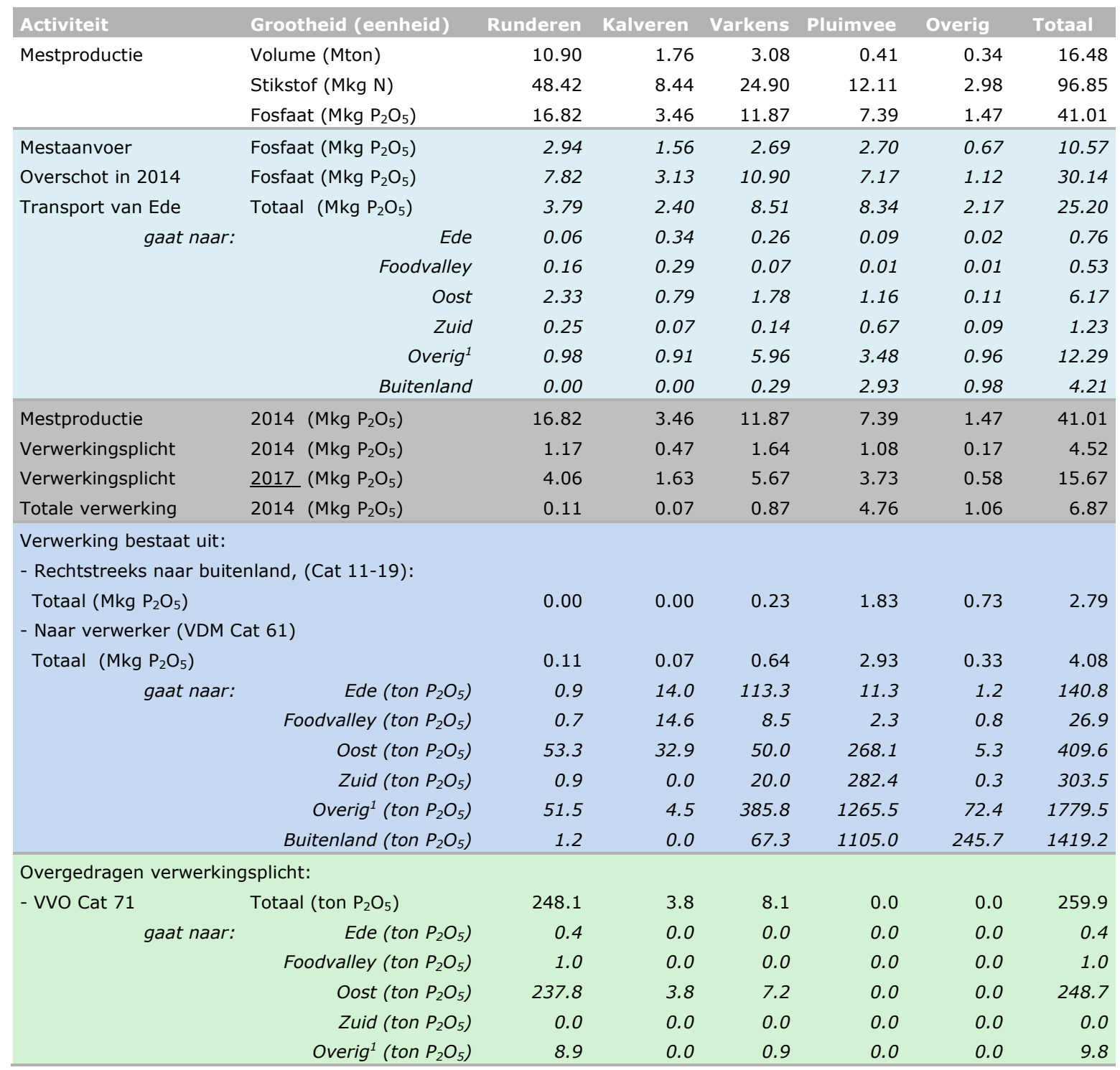

1 Rest van Nederland, particulieren en onbekend. 
Wageningen Environmental Research Postbus 47

6700 AA Wageningen

T 0317480700

www.wur.nl/environmental-research

Wageningen Environmental Research Rapport 2801

ISSN 1566-7197
De missie van Wageningen University \& Research is 'To explore the potential of nature to improve the quality of life'. Binnen Wageningen University \& Research bundelen Wageningen University en gespecialiseerde onderzoeksinstituten van Stichting Wageningen Research hun krachten om bij te dragen aan de oplossing van belangrijke vragen in het domein van gezonde voeding en leefomgeving. Met ongeveer 30 vestigingen, 5.000 medewerkers en 10.000 studenten behoort Wageningen University \& Research wereldwijd tot de aansprekende kennisinstellingen binnen haar domein. De integrale benadering van de vraagstukken en de samenwerking tussen verschillende disciplines vormen het hart van de unieke Wageningen aanpak. 



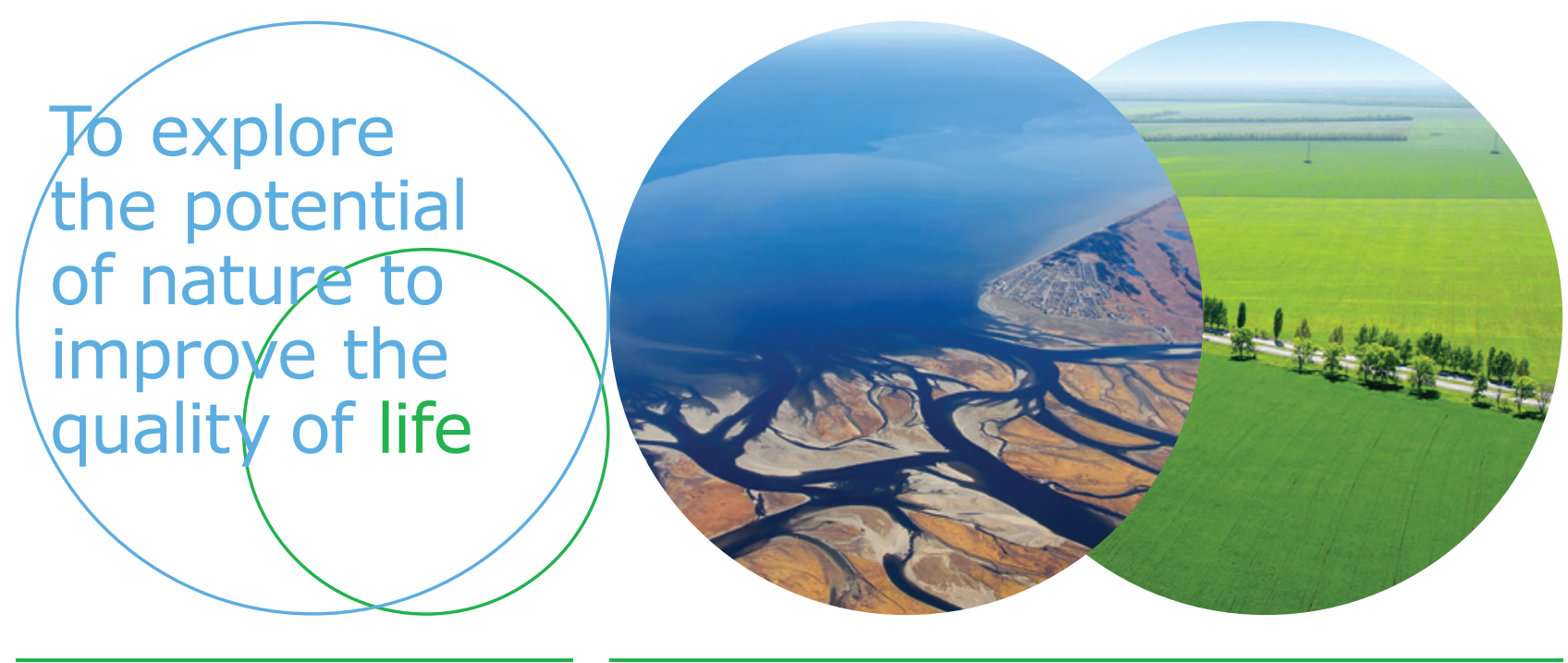

Wageningen Environmental Research Postbus 47

$6700 \mathrm{AB}$ Wageningen

T 317480700

www.wur.nl/environmental-research

Rapport 2801

ISSN 1566-7197
De missie van Wageningen University \& Research is 'To explore the potential of nature to improve the quality of life'. Binnen Wageningen University \& Research bundelen Wageningen University en gespecialiseerde onderzoeksinstituten van Stichting Wageningen Research hun krachten om bij te dragen aan de oplossing van belangrijke vragen in het domein van gezonde voeding en leefomgeving. Met ongeveer 30 vestigingen, 5.000 medewerkers en 10.000 studenten behoort Wageningen University \& Research wereldwijd tot de aansprekende kennisinstellingen binnen haar domein. De integrale benadering van de vraagstukken en de samenwerking tussen verschillende disciplines vormen het hart van de unieke Wageningen aanpak. 